\title{
First report of bovine anaemia associated Theileria sinensis infection and phylogenetic analyses of partial gene sequences of Theileria and Anaplasma species detected in naturally infected Malaysian cattle
}

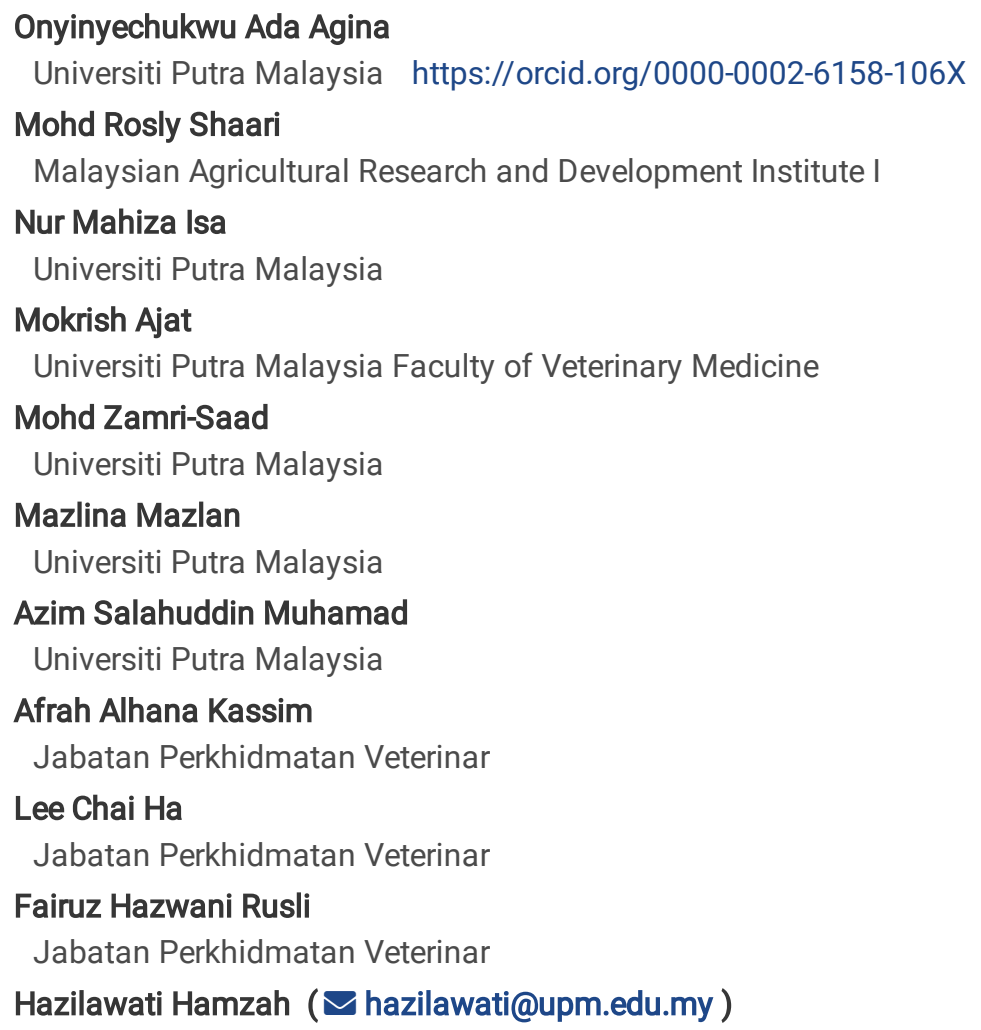

\section{Research}

Keywords: Blood pathogens, PCR, Cattle, Haemato-biochemistry, Erythrocyte fragility, Phylogeny

Posted Date: March 17th, 2020

DOI: https://doi.org/10.21203/rs.3.rs-17415/v1

License: (c) (1) This work is licensed under a Creative Commons Attribution 4.0 International License. Read Full License 


\section{Abstract}

Background: Serious disease outbreaks in cattle are usually associated with blood pathogens. This study aims to detect blood pathogens namely Trypanosoma evansi, Theileria, Anaplasma and Mycoplasma species, and studied their phylogenetic relationships, haematobiochemical abnormalities and erythrocyte osmotic fragility (EOF) in Malaysian cattle.

Methods: Molecular analysis was achieved by PCR amplification and sequencing of PCR amplicons of 18SrRNA gene of Theileria species, 16SrRNA genes of Anaplasma and Mycoplasma species, 16SrRNA gene of Candidatus Mycoplasma haemobos, MPSP gene of $T$. orientalis and RoTaT1.2 VSG gene of Trypanosoma evansi, in sixty-one (61) Kedah-Kelantan X Brahman cattle from Pahang, Malaysia. Haemato-biochemical analyses were performed using automated analysers while EOF was determined with the aid of saline solutions.

Results: PCR amplification produced the expected fragment sizes for MPSP gene of T. orientalis, msp4 gene of Anaplasma marginale, 16S rRNA gene of C. M. haemobos, RoTaT1.2VSG gene of T. evansi. Nucleotide blast demonstrated that sequences of the PCR amplicons showed a high degree of molecular similarity in comparison with reference sequences. Analysis of 18SrRNA gene sequences of Theileria species and 16S rRNA gene sequences of Anaplasma species revealed Theileria sinensis and Anaplasma platys as additional species detected in these cattle. Theileria species was the most detected blood pathogen in the sampled cattle. The blood picture of all cattle group revealed poikilocytosis, anisocytosis, rouleaux formation and degenerative left shift. Erythrocyte fragility values of all the cattle groups were above the reference range. Anaemia of the macrocytic normochromic type was observed in the Trypanosoma evansi; and Anaplasma platys + Theileria sinensis double species co-infected cattle. Normocytic normochromic anaemia was observed in the $T$. sinensis infected cattle group. Significant $(\mathrm{p}<0.05)$ increases in serum liver and kidney parameters, total protein, globulin, total and unconjugated bilirubin and decreased albumin was observed in the Trypanosoma evansi infected cattle.

Conclusion: We present the first report of anaemia associated with Theileria sinensis infection in Malaysian cattle. Because of the high occurrence of bovine theileriosis and detection of Anaplasma platys, there is an urgent need for appropriate preventive and control measures, as Theileria species and A. platys are of great economic and zoonotic importance respectively.

\section{Background}

Theileriosis, anaplasmosis, hemoplasmosis and trypanosomosis are economically important vector-borne diseases of cattle, usually characterized by high morbidity and high mortality in clinical cases [1-4]. These diseases are ranked among the most common causes of economic losses in livestock industry [2]. The Anaplasma, Theileria, Mycoplasma (Hemotropic Mycoplasmas) and Trypanosoma species are the commonly found blood pathogens in Malaysian cattle[1,5] and are transmitted by Ixodid ticks such as Hemaphysalis sp, Boophilus sp, Rhipicephalus sp., and Amblyomma sp [6]. These blood pathogens have constrained cattle production in Malaysia [1], and affected cattle become severely anaemic, anorexic, feverish, jaundice, unthrifty, and dehydrated with increase in plasma proteins, leukopenic, thrombocytopenic, abort or die in severe cases [7, 8]. A consistent feature of these diseases except for trypanosomosis is that, following recovery from primary infection, affected cattle become asymptomatic and persistent carriers, acting as reservoirs of infection to susceptible or immunocompromised animals $[8,9]$. These asymptomatic carriers show low levels of parasitaemia which is usually difficult to detect by microscopy [10]. Therefore, molecular techniques are usually more accurate in diagnosing subclinical infections [11, 12]. Trypanosomosis (Surra) is a mechanically transmitted disease of cattle and horses. It is of high endemicity in tropical and subtropical parts of the world. The causative agent is Trypanosoma evansi, an extracellular flagellated blood protozoan and the most widely distributed pathogenic trypanosome [13]. The acute form of the disease is characterized by anaemia with high mortality in susceptible animals, generalized loss of body condition, reduced fertility, poor immune response and death in protracted cases [14].

Bovine hemoplasmosis is caused by the hemotropic mycoplasmas namely Mycoplasma wenyonii and Candidatus Mycoplasma haemobos which are gram-negative, cell wall-less epierythrocytic rickettsial bacteria found attached onto the surface of erythrocytes [15]. It is associated with severe anaemia, significant haematological disorders, oedema and reproductive problems in affected herd [16, 17]. Anaplasmosis is caused by Anaplasma marginale and A. centrale in cattle [18, 19] and A. platys in dogs, ruminants and humans [20-22]. It is characterized by presence of intra-erythrocytic inclusion bodies, progressive anaemia which may or may not be immune-mediated [23]. Anorexia, icterus, weight loss, decreased milk production, and dehydration are evident in susceptible animals [8]. Bovine theileriosis affects domesticated cattle and is associated with significant reduction in cattle productivity[24]. Theileriosis caused by T. annulata (tropical theileriosis) and T. parva (East coast fever) are of high pathogenicity [25], compared to the benign bovine theileriosis caused by the T. orientalis/buffeli/sergenti complex [25]. Oriental theileriosis is associated with low pathogenicity because T. orientalis schizont infected blood cells are not commonly observed in peripheral blood circulation in ruminants [26]. Recently, serious outbreaks of oriental theileriosis caused by the T. orientalis Ikeda type have been reported in the Asia-Pacific region $[27,28]$. East coast fever caused by T. parva 
predominately affects cattle in Africa, but T. annulata has a world-wide distribution [2]. T. parva and T. annulata are the most pathogenic protozoa in animals [29], and their schizonts causes incomplete neoplastic transformation, proliferation and immortalization of T cells [30]. Theileria sinensis which is a phylogenetically closely related member of T. orientalis complex is known to be the major cause of bovine Theileriosis in China [31] and has been recently reported as one of the causes of benign bovine theileriosis in Malaysia [25]. It is of low pathogenicity in affected cattle [12].

In ruminants, haematology and serum biochemical analyses are relevant for diagnosing haematological disorders and many organ and systemic diseases [32]. Results from such tests (Liver and kidney function test) provide valuable information in the diagnosis, surveillance, making a prognosis and monitoring the disease process (static, progressing or regressing) [33]. Haematological and serum biochemical parameters are usually increased or decreased in blood pathogen infections [34]. The alterations are dependent upon type of infecting species, the infectious dose, virulence, immune status of the host and environmental factors. Anaplasma and Theileria species infects and multiplies inside the red blood cells, and during this intra-erythrocytic stage, intravascular or immune-mediated haemolysis can occur leading to anaemia [35]. Anaemia is a consistent feature in vector-borne diseases, and it is usually as a result of intravascular or extravascular destruction of the red cells. Anaemia of the macrocytic normochromic to macrocytic hypochromic (trypanosomosis) or normocytic normochromic (Anaplasmosis and theileriosis) type is usually evident in affected animals [36]. Immune-mediated hemolytic anaemia has been reported in bovine anaplasmosis and theileriosis [23]. Osmotic erythrocyte fragility test is widely used as an aid to diagnosis of certain haematological disorders such as intravascular haemolytic anaemia, autoimmune diseases, spherocytosis, elliptocytosis and stomatocytosis [37]. Blood parasites cause alteration in the red cell membrane of affected animals thereby making erythrocytes highly susceptible to lysis when subjected to hypo-osmotic stress [37, 38].

The ruminant industry is an integral part of the Malaysian agricultural sector and diseases caused by blood pathogens is one of such diseases with negative impact on it. Therefore, it is essential to improve detection and surveillance of these blood pathogens [39]. Use of light microscopy for identification in stain blood smears are usually ineffective for differentiation of the species and detection of asymptomatic, presymptomatic and carrier animals with low parasitaemia. The use of molecular (PCR) based detection method has enabled better detection of these blood pathogens with high sensitivity and specificity [25, 29]. A need to determine the phylogenetic relationships and to have a better molecular taxonomic understanding of the infections caused by various species of commonly occurring blood pathogens in Malaysian cattle is required. Therefore, this present study provides the molecular occurrence of Theileria species, Trypanosoma evansi, Candidatus M. haemobos and Anaplasma species isolates in Muadzam Pahang Malaysia and ascertained the haemato-biochemical abnormalities and erythrocyte osmotic fragility in Kedah-Kelantan X Brahman crossbred cattle infected by these blood pathogens.

\section{Methods}

\section{Ethical statement}

This study was conducted according to the guidelines of the Animal Care and Use Committee, Universiti Putra Malaysia, Animal Welfare Act.

\section{Study population and blood sampling}

A total of 61 blood samples of $5 \mathrm{ml}$ each were obtained by coccygeal venipuncture from randomly selected Kedah-Kelantan $\mathrm{x}$ Brahman cattle of varying ages (1-11 years old) and sex (male and female) at Muadzam Pahang, Malaysia. The animals were reared in an oil palm plantation, and graze forages under palm oil plantation with some mineral supplementation. Animals were physically observed, and clinical signs were noted before blood samples were obtained. The blood samples were placed in a pre-labelled K2 EDTA vacutainer tubes for haematological determinations, heparin blood vacutainers for erythrocyte osmotic fragility and plain vacutainers to harvest sera for biochemical determinations. The samples were then transported in an ice box to the haematology and clinical biochemistry laboratory, Universiti Putra Malaysia. Whole blood samples for PCR was stored at $-80^{\circ} \mathrm{C}$ prior to DNA extraction. Extracted genomic DNA was subjected to genera and species-specific PCR test for detection of these blood pathogens.

\section{Microscopic examination of stained thin-blood smears}

Examination of Giemsa stained thin-blood smear for possible identification of blood pathogens were performed by light microscopy.

\section{Determination of haemato-biochemical parameters}


Erythrocytic parameters, platelet, total leukocyte and differential leukocyte counts were performed using automated haemoanalysers (Advia 2120i Siemens-Healthineers, Malvern, USA). Packed cell volume was performed using the micro-haematocrit technique with the aid of haematocrit centrifuge (Haematokrit 20, Hettich Zentrifugen, Tuttlingen, Germany), and Hawksley micro-haematocrit reader (Hawksley, England). Sera were harvested using portable table centrifuge (EBA 20 Hettich Zentrifugen, Tuttlingen, Germany). Serum sodium, potassium and chloride were determined using Siemens xpand plus chemistry analyser (Siemens Healthineers, Malvern, USA). Serum aspartate aminotransferase (AST), alkaline phosphatase (ALP), gamma glutamyltransferase (GGT), total bilirubin (TB), total protein (TP), albumin (ALB), conjugated bilirubin (CB), inorganic phosphate (IP), urea, and creatinine were done using BiOLis 24i premium chemistry analyser (DiaSystem Scandinavia AB, Sweden). Globulin was obtained by subtracting the albumin value from total protein value. Albumin, globulin ratio was calculated by dividing the albumin value with the globulin value. Plasma protein was determined using a hand-held refractometer (Atago, USA) while icteric index was determined by comparing the colour of test plasma sample with a set of colour standards.

\section{Erythrocyte osmotic fragility test}

Erythrocyte osmotic fragility (EOF) was determined by subjecting erythrocytes to varying concentrations of buffered saline solutions with slight modification [40,41]. Briefly, $5 \mathrm{ml}$ of different buffered saline concentrations of $\mathrm{pH} 7.4$ ranging from $0.1 \%$ to $0.9 \%$ were pipetted into 5 test tubes arranged serially in a test tube rack. A set of 5 test tubes was used to analyse each sample. Whole blood (20 $\mu$ l) was pipetted into each 5 test tubes and mixed thoroughly by inverting the test tubes several times to mix the content. The mixed blood was incubated at room temperature for 20 minutes. The content was mixed again before spinning at $1500 \mathrm{xg}$ for 15 minutes. The supernatant was transferred into cuvette and read at an absorbance of $540 \mathrm{~nm}$ using a spectrophotometer (Tecan Biochem, USA). The percentage haemolysis was calculated with the following formula:

Haemolysis (\%): (Optical density of test/Optical density of distilled water) x 100

The EOF curve was obtained by plotting the haemolysis percentage against the different saline concentration. The result of the EOF is expressed as the saline concentration that caused $50 \%$ haemolysis, which is the mean cell fragility (MCF).

\section{Genomic DNA extraction}

Genomic DNA was extracted from whole blood stored at $-80^{\circ} \mathrm{C}$ using the DNeasy® Blood and Tissue kit (Qiagen, Hilden Germany) according to the manufacturers' protocol with minor modification. Briefly, $20 \mu$ of proteinase $\mathrm{K}$ and $200 \mu \mathrm{l}$ of Buffer AL was added into $200 \mu \mathrm{l}$ of whole blood samples in a $2 \mathrm{ml}$ microcentrifuge tube. The mixture was vortexed and incubated at $56^{\circ} \mathrm{C}$ for 10 minutes. After incubation, $200 \mu \mathrm{l}$ of $100 \%$ ethanol was added into the mixture and thoroughly vortexed. The mixture was pipetted into a spin column and placed in a $2 \mathrm{ml}$ collection tube. This was centrifuged at $6000 \mathrm{xg}$ for 1 minute. The flow through was discarded and the spin column was placed in a fresh $2 \mathrm{ml}$ collection tube. $500 \mu$ of buffer AW1 was pipetted into the spin column and centrifuged for 1 minute at $6000 \mathrm{x}$ g. Flow- through and collection tube were discarded. The spin column was placed in a new $2 \mathrm{ml}$ collection tube and $500 \mu \mathrm{l}$ of buffer AW2 was added. This was centrifuged for 3 minutes at $2000 \mathrm{xg}$ to dry the DNeasy membrane. The flow-through and collection tube was discarded. The spin column was placed in a $2 \mathrm{ml}$ microcentrifuge tube and $200 \mu \mathrm{l}$ of buffer AE was pipetted directly onto the DNeasy membrane. After incubating at room temperature for 1 minute, the spin column was centrifuged for 1 minute at $6000 \mathrm{xg}$ to elute the DNA. The eluted DNA was stored at $-20^{\circ} \mathrm{C}$ until use. DNA concentration and purity were measured with a Nanodrop spectrophotometer (Tecan Infinite $M 200 \AA$, Austria). DNA samples with $A_{260} / A_{280}$ ratios between $1.7-2.2$ were further analysed.

\section{Molecular identification by PCR}

Polymerase chain reaction test was done to amplify the partial gene fragments of Theileria, Mycoplasma and Anaplasma species using genus and species-specific primer sets (Table $1 \&$ 2). Detection of RoTaT 1.2 VSG gene for T. evansi was done using species-specific primer set (Table 2). Thermocyclic conditions and primers for Anaplasma, Theileria and Mycoplasma species were as specified by Parola et al. [42]; Sogin et al. [43]; and 1990 and Su et al. [44] respectively. Thermocyclic conditions and primers for Anaplasma marginale, Theileria orientalis, Trypanosoma evansi and Candidatus Mycoplasma haemobos were as specified by Shkap et al. [45], Ota et al. [46], Urakawa et al. [47] and Su et al. [44] respectively. Each PCR run was performed in a final volume of $25 \mu$ reaction in 0.2 ml PCR reaction tubes, comprising of $0.3 \mu \mathrm{l}$ of $10 \mathrm{mM}$ dNTP mix (dATP, dCTP, dGTP, dTTP), $1 \mu$ of $10 \mu \mathrm{M}$ of each primer, $5 \mu$ of $5 \mathrm{X}$ Green GoTaq ${ }^{\circledR}$ flexi buffer (Promega Madison WI, USA), $5 \mu$ of $25 \mathrm{mM} \mathrm{MgCl}_{2}, 0.3 \mu \mathrm{l}$ of $5 \mathrm{U}$ GoTaq ${ }^{\circledR} \mathrm{G} 2$ flexi DNA polymerase (Promega Madison WI, USA), 8.4 $\mu \mathrm{l}$ of water for molecular biology ((Millipore corporation, Billerica MA, USA) and $4 \mu \mathrm{l}$ of template DNA. The positive control DNA used in the PCR run consisted of a field isolate confirmed by PCR and sequencing of the amplicon, and was obtained from the Veterinary Parasitology Laboratory, Universiti Putra Malaysia. Water for molecular biology (Millipore corporation, Billerica MA, USA) was used as a 
negative control. PCR amplification was performed using the BioER Little Genius ${ }^{\circledR}$ LED thermal cycler (Hangzhou Bioer Technology China) with the primer sequences and thermocyclic conditions for each blood pathogen presented in Tables 1-2. Amplified products were then analysed by electrophoresis on a 1.2-1.5\% agar rose gel for 80 minutes at 80 voltage. The gel was stained with RedSafe ${ }^{\mathrm{TM}}$ (iNtRoN Biotechnology, Korea) for 10 minutes and visualized using a UV transilluminator (GeneDireX ${ }^{\mathrm{TM}}$, USA).

All samples positive for $18 \mathrm{~S}$ ribosomal RNA gene of Theileria species and 16S ribosomal RNA genes of Mycoplasma and Anaplasma species were further amplified by conventional PCR using species-specific primer set (Table 1), targeting major piroplasm surface protein (MPSP) gene for T. orientalis, major surface protein 4 ( $m s p 4)$ gene for $A$. marginale and 16S ribosomal RNA of Candidatus M. haemobos.

\section{Sequencing of PCR products}

Amplicons from each blood pathogen species with clear bright bands were selected for sequencing. They were gel extracted and purified using QIAquick gel extraction kit (Qiagen, Hilden, Germany) according to the manufacturers' protocol. The amplicons were sequenced using the BigDye® Terminator v3.1 cycle sequencing ready reaction kit (Applied Biosystems, USA). Consensus sequences were obtained for all PCR products using BioEdit Sequence Alignment Editor Software (version 7.0.5.3). The resulting nucleotide sequences were analysed and compared for similarities with reference sequences from GenBank database, using the Basic Local Alignment Search Tool (BLAST) program (http://www.ncbi.nlm.nih.gov/BLAST.cgi).

Amplicons found to be negative for T. orientalis, A. marginale and C. M. haemobos after the species-specific primer sets were used, were sequenced using their respective genus primer sets. The obtained sequences were then compared with reference sequences deposited in the GenBank.

\section{Phylogenetic analysis}

Our sequences from the various PCR amplicons were supplemented with reference sequences from GenBank and were aligned using ClustalW algorithm. After alignment, regions with gaps were removed manually and gap-free sites were used to construct phylogenetic trees using maximum likelihood method in MEGA software version X [48]. The reliability for the internal branches of maximum likelihood was assessed using 1000 bootstrap re-samplings and molecular distances estimated by the general time reversible model [49].

Five (5) and fourteen (14) sequences of the corresponding PCR products obtained with the MPSP and 18SrRNA primer sets for Theileria orientalis and Theileria $s p$. respectively were analysed using BLASTn to confirm their identities. They were then compared with MPSP sequences of T. orientalis from Sri Lanka (LC438477.1; AB701444), Thailand (KU886285.1; KU886290.1; AB562570), Mongolia (AB602388.1), China (KU356867.1), Vietnam (LC125432.1), Myanmar (AB871365.1), China (KX375396.1) and 18SrRNA sequences of $T$. sinensis isolates from China (KF559355.1; EU274472.1; HM538203.1). In addition to T. orientalis and T. sinensis, a closely related species T. sergenti (AB000271) isolate from Japan was included in the phylogenetic tree for comparison. Plasmodium malariae (MF796946.1) isolate from Thailand was used as an outgroup.

The phylogenetic analysis of the $m s p 4$ gene was performed as described above using the maximum likelihood method. The five msp4 genes of $A$. marginale, two 16S rRNA gene of Anaplasma species isolates from this study, msp4 and 16S rRNA reference gene sequences were used for the comparison and creation of a phylogenetic tree for Anaplasma species. The reference sequences with their accession numbers in GenBank and country of origin are presented as follows: The $m s p 4$ sequences of $A$. marginale isolates from Thailand (MK140740.1; MH939156.1), Mozambique (MH172467.1; MH026093.1), India (MG676459.1; KX989517.1), Brazil (MK570463.1), Cuba (MK809386.1), Colombia (MF771080.1) and 16Sr RNA sequences of A. platys isolates from India (MG050139.1), Brazil (JX392984.1), China (KU585997.1). Plasmodium falciparum isolate (EY977394.1) from UK was used as an outgroup.

The Kedah-Kelantan X Brahman cattle were later divided into 8 categories based on the number of infecting blood pathogens; single species, double species co-infection, and triple species co-infection following PCR amplification of species-specific genes.

\section{Statistical analysis}

All data, expressed as mean \pm standard deviation of mean, were normally distributed ( $P>0.05$, Shapiro-Wilk's test). One-way multivariate analysis of variance (MANOVA), followed by Duncan multiple post hoc comparison test, was applied to study the effect of varying concentrations of saline solutions on erythrocytes. One-way analysis of variance (ANOVA) followed by Duncan post hoc comparison test were applied on the data generated from the haemato-biochemical parameters and mean cell fragility of the different groups of cattle. Mean cell fragility values were extrapolated from the erythrocyte osmotic fragility curves. Statistical analysis was performed using SPSS 25.0 (Chicago IL, USA). A Probability value $<0.05$ was considered as statistically significant. 


\section{Results}

\section{Microscopic examination of thin blood smears}

No Theileria piroplasms or schizonts were detected in the blood cells. Anaplasma morula were absent in the erythrocytes and $C$. M. haemobos were not seen attached onto the surface of erythrocytes. Numerous $T$. evansi were seen in the thin blood smear as elongated extracellular protozoan parasites (Figure 1). The blood picture of all cattle group revealed the presence of echinocytes, elliptocytes, macrocytes, anisocytosis, few acanthocytes, rouleaux formation and numerous immature neutrophils (Figures 1-5). Clinical signs such as anorexia, profuse ocular discharge, dyspnoea and recumbency in few animals were observed.

\section{Identification, percentage occurrence and similarity analysis of the blood pathogens detected in the KK x Brahman cattle}

Molecular analysis by PCR amplification using genus specific primers produced expected fragment sizes of 1750 bp for $18 \mathrm{~S}$ rRNA gene of Theileria species (Figure 6) in, 345 bp for 16SrRNA gene of Anaplasma species (Figure 7) and 280 bp for 16SrRNA gene of Mycoplasma species (Figure 8). Theileria species were detected in 44 (72.13\%) of sampled cattle and was the most occurring blood pathogen, followed by Mycoplasma species in 25 (40.98 \%) cattle, Anaplasma species in 15 (24.59\%) cattle and Trypanosoma evansi in 2 (3.28\%) (Figure 9) of the sampled cattle. To identify and further confirm the specific species of blood pathogens detected in the cattle, PCR amplification using species-specific primers produced expected fragment of $776 \mathrm{bp}$ of the major piroplasm surface protein (MPSP) gene of T. orientalis (Figure 10) in $20(32.8 \%)$ cattle, 761 bp of major surface protein 4( $m s p 4)$ gene of Anaplasma marginale (Figure 11) in $15(24.6 \%)$ cattle, 279 bp of 16SrRNA gene of Candidatus Mycoplasma haemobos (Figure 12) in 25 (41) cattle, and 205 bp of RoTaT 1.2 VSG gene of Trypanosoma evansi (Figure 13) in $2(3.3 \%)$ cattle. Sequencing of T. orientalis PCR amplicons demonstrated $95 \%$ molecular similarity with reference sequences from Thailand (AB562570.1), Vietnam (LC125432.1), Sri Lanka (LC438477.1; AB701444.1), Myanmar (AB871365.1) and China (KU356867.1). Twenty-four (24) out of Forty-four (44) Theileria species PCR amplicons, which were negative for T. orientalis were amplified using the $18 \mathrm{~S}$ rRNA gene primer sets. Fourteen (14) out of 24 amplicons were randomly selected for sequencing. Similarity analysis using nucleotide BLAST (BLASTn) demonstrated that those fourteen (14) negative T. orientalis PCR amplicons corresponded to Theileria sinensis and shared a high degree of molecular similarity (99.5\%1-99.87\%) in comparison with reference sequences from China (KF559355.1; EU274472.1; HM538203.1).

The fifteen (15) positive 16S ribosomal RNA gene of Anaplasma species isolates further subjected to a species-specific PCR using msp4 primer set, revealed that 13 out of 15 amplicons were positive for $A$. marginale. The amplicon sequences for $m s p 4$ gene of $A$. marginale and 16S rRNA of Anaplasma species demonstrated $99 \%-100 \%$ similarity for $A$. marginale reference sequences from Western Cuba (MK809386), Brazil (KM624516), Thailand (MK140740) and India (KX989516). The 2 amplicons negative for A. marginale was sequenced using 16S rRNA primer set and demonstrated 99\% similarity for Anaplasma platys reference sequences from China (KU586159.1) and Brazil (JX392984.1), and 98\% similarity with Anaplasma platys isolate from India (MG050139.1). Similarity analysis using BLASTn demonstrated that sequences of 16S rRNA gene of C. M. haemobos isolates from this study shared a high degree of molecular similarity (99.55\% - 100\%) with reference sequences from (JN314393.1), Mozambique (MF992084.1), Japan (EU367965.1), Malaysia (KT985638.1), Cuba (MG948633.1), Brazil (JN314393.1), China (MH388479.1), and Philippines (MK328955.1). Amplicon sequences for RoTaT1.2 VSG gene of T. evansi isolates from this study demonstrated $100 \%$ molecular similarity with isolates from Kenya (MK867833), India (KY457409.1; AB259839.1) and Egypt (KF726106; JX888091).

\section{Percentage occurrence of single, double and triple species co-infection in Kedah-Kelantan X Brahman cattle}

A total of six species of blood pathogens were detected by PCR and sequencing of amplicons and these include Theileria orientalis, Theileria sinensis, Anaplasma marginale, Anaplasma platys, Candidatus M. haemobos and Trypanosoma evansi. A high percentage $(89 \%)$ of the sampled cattle were co-infected with more than one blood pathogen. Analysis of blood pathogen single species infection among the sampled cattle revealed that $15 \%$ of sampled cattle were infected by $T$. sinensis while sole infections with $C$. M. haemobos infected cattle and $T$. evansi were $8 \%$ and $3 \%$ respectively (Figure 14). Theileria sinensis $+C$. M. haemobos had the highest double species co-infection (31\%), followed by $T$. orientalis $+A$. marginale $(17 \%), T$. orientalis $+T$. sinensis $(15 \%)$, and the lowest being A. platys $+T$. sinensis (3\%) (Figure 14). Candidatus M. haemobos + T. sinensis + A. marginale triple species co-infection was detected in $8 \%$ of the sampled cattle (Figure 14). T. sinensis + C. M. haemobos species co-infection had the highest occurrence while C.M. haemobos+ T. sinensis+ A. marginale triple species co-infection was the least (Figure 14).

\section{Phylogenetic analysis}


Phylogenetic analyses were done to determine whether the vector-borne blood pathogens detected in this study are genetically diverse within different geographical regions of the world. Phylogenetic analysis based on the MPSP gene of $T$. orientalis grouped Malaysian isolates, TO 34 and TO 41 together with reference isolates from Myanmar (AB871365.1) and China (KX375396.1). Sri Lanka, Thailand and Mongolia reference isolates grouped together and formed a separate branch from our Malaysian isolates TO 14 and TO 61 (Figure 15). Malaysian isolate TO 17 grouped together with China (KU356867.1) and Thailand (AB562570) reference sequences from GenBank. Analysis based on the 18S rRNA gene grouped all our Theileria sinensis isolates in the same branch as the $T$. sinensis reference isolates from China (KF559355.1; EU274472.1; HM538203.1) and T. sergenti (AB000271) (Figure 15).

Phylogenetic analysis based on msp4 gene grouped our 5 isolates together with reference sequences from Cuba, Mozambique, Brazil, India, Thailand and Colombia (Figure 16). Five A. marginale msp4 gene sequences from this study formed separate branches with our two A. platys sequence (Figure 16). A 95\% bootstrap support of reference sequences from India (MG050139.1) and Brazil (JX392984.1) were formed with our two A. platys sequences (Figure 16).

\section{Haemato-biochemical and electrolyte abnormalities in the different cattle groups}

The haemato-biochemical parameters and electrolyte levels in the KK X Brahman crossbred cattle were presented in Tables 3-6. The cattle were divided into 8 groups based on the PCR amplification and sequencing of the PCR amplicons. The groups were as follows: T. evansi infected cattle; Candidatus M. haemobos infected cattle; T. sinensis infected cattle; T. orientalis $+A$. marginale infected cattle; $A$. platys + T. sinensis infected cattle; T. sinensis+ C. M. haemobos; T. orientalis + T. sinensis infected cattle; C. M. haemobos+ T. sinensis $+A$. marginale infected cattle groups. A significant ( $\mathrm{p}<0.05)$ decrease in mean PCV, RBC, Hb and high mean cell volume (MCV), icteric index and a MCHC within the reference range were recorded in the $T$. evansi infected groups. Plasma protein value was significantly $(p<0.05)$ high in all cattle groups with that of the $T$. evansi being highest. Cattle positive for $T$. sinensis had significant $(p<0.05)$ decreased RBC, Hb with normal PCV and icteric index. Significantly $(p<0.05)$ decreased RBC count and Hb value with a high MCV and normal PCV value were recorded in the A. platys $+T$. sinensis cattle group. Significant $(\mathrm{P}<0.05)$ increase in mean plasma protein value were observed in all cattle groups. The mean relative diameter width (RDW) of $C$. M. haemobos and T. orientalis $+A$. marginale infected cattle groups were significantly $(p<0.05)$ lower than that of other cattle groups. There were no significant $(p>0.05)$ difference in the mean values of $M C H C$ and platelet count of all cattle groups. All blood pathogen infected cattle groups had significantly $(p<0.05)$ high myelocyte, metamyelocyte, band and segmented neutrophil values, with a normal promyelocyte, lymphocyte, basophil, white blood cell counts. Mean eosinophil count was significantly $(\mathrm{p}<0.05)$ decreased in the $T$. evansi group when compared to other cattle groups (Table 2$)$. Significant $(p<0.05)$ increase in mean values of sodium, potassium and chloride were recorded across all cattle groups, with a significant increase in mean creatinine and urea values recorded only in the T. evansi infected group (Table 3). Significant increases in serum ALP, AST, GGT activities, total protein, globulin, total and conjugated bilirubin and decreased mean serum albumin value was observed in the $T$. evansi cattle group when compared to the other infected cattle groups (Table 4). The mean serum alkaline phosphatase (ALP) value of the $T$. sinensis cattle was lower than that of other cattle groups and the reference range of values. Mean serum total protein and globulin values were increased in the T. evansi, C. M. haemobos and T. orientalis $+A$. marginale infected cattle group. Low albumin with low albumin: globulin ratio was recorded in the $T$. evansi group, while albumin:globulin ratio was decreased across all cattle groups. A significant $(p<0.05)$ increase in mean serum total and unconjugated bilirubin values of the $T$. evansi cattle when compared to the other cattle groups (Table 4).

\section{Mean erythrocyte osmotic fragility}

The erythrocyte osmotic fragility curves showed an evident shift to the right in all cattle groups, with the $T$. evansi osmotic fragility curve being farthest, followed by the $T$. sinensis fragility curve (Figure 17). Duncan's post hoc comparison test showed an increase of erythrocyte osmotic fragility at $0 \%, 0.1 \%, 0.3 \%, 0.5 \%, 0.7 \%$ and $0.9 \%$ saline concentration in all cattle groups (Figure 17 ). The mean cell fragility (MCF) values of all the cattle groups were above the reference range $(0.40-0.45 \%)$ and at all sodium chloride $(\mathrm{NaCl})$ concentrations, no significant ( $p>0.05$ ) difference was recorded in the EOF values of all cattle groups (Figure 18).

\section{Discussion}

Theileria species were the highest occurring blood pathogen in the sampled cattle, with $T$. sinensis being the most detected Theileria species. Theileria sinensis is the major causative agent of benign bovine theileriosis in China [31]. Therefore, it's detection in Malaysian cattle suggests possible introduction or importation or close contact of asymptomatic carrier cattle to naïve cattle in Malaysia. However, it would be worthy to investigate whether $T$. sinensis is now indigenous to Malaysia or whether it was introduced from China. The sequence similarity among the Malaysian isolates and those in other parts of the world might have been caused by the movement/importation of

Page $7 / 33$ 
cattle into South-East Asia. This study also reports the presence of Anaplasma platys which is a rickettsial bacteria that infects a wide range of host such as man, horses, small ruminants and dogs [20,21]. Our discovery of this species in cattle agrees with Chien et al. [22], who reported same for Vietnamese cattle. Detection of $A$. platys raises an urgent concern about the zoonotic implication of this blood pathogen in Malaysia.

The blood pathogen infections caused significant changes in haemato-biochemical parameters of the $T$. evansi infected cattle; $T$. sinensis infected cattle; and A. platys + T. sinensis double species co-infected cattle groups. Haemato-biochemical abnormalities in T. evansi infected cattle include a mild macrocytic normochromic anaemia, high icteric index, degenerative left shift, eosinopenia, hypernatraemia, hyperkalaemia, hyperchloridaemia, azotaemia (high creatinine and urea level), increased serum liver enzyme (ALP, AST, GGT) activities, hyperproteinaemia with hypoalbuminaaemia, and hyperglobulinaemia, low albumin:globulin ratio, hyperbilirubinaemia due to increased unconjugated bilirubin level. Anaemia in trypanosomosis include mechanical injury to erythrocytes and subsequent lysis caused by the lashing action of trypanosoma flagella and attachment of the trypanosomes onto red cell surface via sialic acid receptors [50]. Other causes of anaemia in T. evansi include fever, toxins and metabolites from trypanosomes (proteases, neuraminidase, phospholipases, free fatty acids), dyserythropoiesis, lipid peroxidation and malnutrition [4,51]. Elevation in serum total and unconjugated bilirubin in the $T$. evansi group was due to massive intravascular haemolysis with increased release and breakdown of haemoglobin and conversion to bilirubin by macrophages in the spleen and other mononuclear phagocyte system. Free bilirubin is transported to liver when bound to albumin for conjugation with glucuronic acid. If the rate of bilirubin production exceeds the rate at which the conjugation takes place, there will be increase in the concentration of unconjugated bilirubin in plasma, and hence high icteric index [52]. Elevation of liver enzyme activities in the T. evansi group was attributed to cellular hypoxia and/or centrilobular necrosis due to low liver blood volume that leads to hepatocyte injury [52]. This hepatocellular injury could have contributed to slow rate of bilirubin conjugation. Albumin is a negative acute phase protein which decreases in acute inflammatory conditions, therefore Induction of inflammatory condition by the trypanosomes could have led to hypoalbuminaemia and hyperproteinaemia due to hyperglobulinaemia. Albumin:globulin ratio decreases with increase in inflammation. Increased urea and creatinine levels in T. evansi infected cattle could be attributed to possible damage to the kidneys or renal insufficiency caused by the toxic metabolites of the protozoa [53].

The haemato-biochemical abnormalities associated with $T$. sinensis infection in cattle include mild normocytic normochromic anaemia, degenerative left shift, hyperproteinaemia with a low albumin:globulin ratio, hyperkalaemia, hypernatraemia, hyperchloridaemia and low serum alkaline phosphatase activity. Mild anaemia recorded in $T$. sinensis infected cattle group could be attributed to extravascular haemolysis of abnormal shaped red cells by the mononuclear phagocyte system [54]. The finding of normocytic normochromic anaemia in bovine theileriosis agrees with [34].

Haematology and serum biochemistry findings in the A. platys $+T$. sinensis cattle group include decreased RBC count and $\mathrm{Hb}$ concentration with a high MCV and normal PCV value. Normal PCV value with a low red blood count and haemoglobin concentration is highly suggestive of a decrease in plasma volume due to dehydration. Therefore, a macrocytic normochromic anaemia reported in this cattle group, is responsive because anisocytosis and macrocytic indices supports regenerative status in ruminants [55]. Degenerative left shift, hypernatraemia, hyperkalaemia, hyperchloridaemia, hyperproteinaemia with low albumin:globulin ratio were other haematobiochemical features reported in the $A$. platys $+T$. sinensis double species co-infection.

Haemato-biochemical abnormalities in other blood pathogen infected cattle groups without anaemia such as the $C$. $M$. haemobos infected cattle group, had erythrocytes of low relative diameter width (RDW), degenerative left shift, hyperproteinaemia with a low albumin:globulin ratio, hypernatraemia, hyperkalaemia and hyperchloridaemia. The erythrocytes of Theileria orientalis $+A$. marginale infected cattle group had a low RDW, hyperproteinaemia with a low albumin:globulin ratio, degenerative left shift, hypernatraemia, hyperkalaemia and hyperchloridaemia. T. sinensis + C. M. haemobos infected cattle group had degenerative left shift, hyperproteinaemia with low albumin:globulin ratio, hypernatraemia, hyperkalaemia and hyperchloridaemia. Theileria orientalis + T. sinensis double species co-infection showed degenerative left shift, hyperproteinaemia with a low albumin:globulin ratio, hypernatraemia, hyperkalaemia and hyperchloridaemia in their haemato-biochemical profile. The cattle group infected with all 3 blood pathogen genera (C. $M$. haemobos+T. sinensis $+A$. marginale) had a low-normal red blood cell count, degenerative left shift, hypernatraemia, hyperkalaemia and hyperchloridaemia, high serum gamma glutamyl transferase activity and hyperproteinaemia with a low albumin:globulin ratio.

Relative diameter width (RDW) is a measure of anisocytosis [56], and a low or narrow RDW observed in the $C$. M. haemobos and T. orientalis + A. marginale cattle groups signifies the presence of larger than normal sized red cells (macrocytes) in these cattle [32]. Increased globulin concentration in the T. evansi, C. M. haemobos and T. orienatlis + A. marginale infected cattle groups indicates an ongoing inflammatory condition consequent upon rickettsial bacteria or protozoal infections. Hyperglobulinaemia leads to increase in circulating immunoglobulins in response to the invading pathogens by the host immune system [57].

Page $8 / 33$ 
Degenerative left shift was the commonest feature observed in all the blood pathogen infected cattle groups was highly suggestive of a severe inflammatory condition. This signifies that the demand for neutrophils from an inflammatory foci is overwhelming and granulopoietic capacity has been exceeded $[58,59]$. The functional storage compartment of mature neutrophils in the bone marrow of cattle is low when compared to other mammalian species [60], and in severe inflammatory conditions, increased demand for neutrophils rapidly exhausts the marrow storage pool and immature neutrophils such as the band, metamyelocyte and myelocyte are released into the peripheral circulation. Rickettsial bacteria and protozoal infections tend to cause an immunosuppression that makes the host susceptible to secondary infections. Natural infection of cattle by these blood pathogens induced an increase of erythrocyte osmotic fragility. This suggest that even when the blood pathogens have been cleared or reduced from peripheral circulation, they 'left behind' red blood cells with altered cell membrane that are susceptible to hypo-osmotic stress. Also, abnormal red blood cell shapes (echinocytes, elliptocytes, acanthocytes, macrocytes) due to an altered cell wall might have attributed to cell membrane instability and thus, increased fragility [7]. It is physiologically expected that fewer RBCs should hemolyse at higher saline concentration ( $0.9 \%)$, but in this case, more RBCs were still haemolysed at this concentration suggesting that RBC membrane has been compromised by the effect of the blood pathogens. Also, the erythrocyte osmotic fragility curves exhibited a rightward shift and this further confirmed the increased instability of red blood cell membrane induced by the blood pathogens [61]. In general, blood pathogens induce structural, biochemical and functional damage to the erythrocyte membrane (degradation of the membrane polyunsaturated fatty acids) and makes them vulnerable to reactive oxygen species and susceptible to haemolysis [7,37].

Our finding of hypernatraemia in all cattle groups was not in agreement with [62], who reported a hyponatraemia in theileria infected cattle. Therefore, we suggest that there might have been a decrease in serum sodium level but was probably masked by dehydration. Hyperkalaemia and hyperchloridaemia observed in all cattle groups were attributed to pre-renal dehydration [63]. The Theileria orientalis, Candidatus M. haemobos, and Anaplasma marginale infection confirmed in the sampled cattle by PCR test were considered to be subclinical/asymptomatic based on the absence of anaemia, blood pathogens on thin blood smears, presence of blood pathogen DNA and presence of non-specific clinical symptoms.

\section{Conclusion}

Trypanosomosis, theileriosis due to $T$. sinensis and A. platys $+T$. sinensis double species co-infection were observed to be the main causes of anaemia in the affected herd. Therefore, we present the first report of anaemia associated with $T$. sinensis; and Anaplasma platys $+T$. sinensis double species co-infection in Malaysian beef cattle. Anisocytosis, poikilocytosis, degenerative left shift, increased plasma protein, hyperkalaemia, hypernatraemia, hyperchloridaemia and normal lymphocyte, leukocyte and platelet counts were consistent findings in all groups of cattle. Both $T$. evansi and T. sinensis infected cattle with low erythrocytic values and other blood pathogen infected cattle groups with normal erythrocytic values possess circulating erythrocytes that are very susceptible to hypoosmotic stress. Discovery of $A$. platys in cattle raises a considerable concern about zoonotic transmission in Malaysia, as this species can infect man. It is pertinent to know a current status of the commonly occurring blood pathogens that affect the ruminant industry and design natural control measures for mitigating the issues facing this aspect of the agricultural sector in Malaysia.

\section{Declarations}

\section{Authors' contributions}

Conception and study design: HH \& OA developed and designed the study. Methodology: HH, OA, MRS, MA, MM, MZS, AS, LC, FH \& AA. Data collection: OA, HH, MRS, MA, MM \& MZS. Data analysis \& Interpretation: OA \& HH. Intellectual interpretation of the findings: HH \& OA. Manuscript draft and revision: OA \& HH. All authors read and approved the final manuscript.

\section{Funding}

This work was funded by the Ministry of Education Malaysia (MOE) (FRGS/1/2019/WAB01/UPM/02/2) and IPS Research Grant, Universiti Putra Malaysia (GP-IPS/2018/9617000). PhD scholarship was provided by the Tertiary Education Trust Fund (TETFund) Nigeria (2016/2017AST\&D).

\section{Acknowledgements}

The authors will like to thank the staff of Veterinary Haematology and Clinical Biochemistry Laboratory and Veterinary Parasitology Laboratory, Universiti Putra Malaysia for providing technical assistance. 
All data generated and analysed during the study are included in this published work.

\section{Ethics approval and consent to participate}

This study was approved by the Universiti Putra Malaysia Animal Care and Use Committee and all guidelines for the use of animals were followed.

\section{Consent for publication}

Not applicable.

\section{Competing interests}

The authors have no competing interest in submission and publication of data in this article.

\section{References}

1. Tay ST, Koh FX, Kho KL, Ong BL. Molecular survey and sequence analysis of Anaplasma spp. in cattle and ticks in a Malaysian farm. Trop Biomed. 2014;31:769- 76.

2. Moumouni A, Franck P, Aboge GO, Terkawi MA, Masatani T, Cao S, et al. Molecular detection and characterization of Babesia bovis, Babesia bigemina, Theileria species and Anaplasma marginale isolated from cattle in Kenya. Parasit $\quad$ Vectors; 2015;8:1-14.

3. Mohd Hasan LI, Kho KL, Koh FX, Hassan Nizam QN, Tay ST. Molecular evidence of hemoplasmas in Malaysian cattle and ticks. Trop Biomed. 2017;34:668-74.

4. Ereqat S, Nasereddin A, Jawabreh A Al, Jawabreh H Al, Laham N Al. Prevalence of Trypanosoma evansi in livestock in Palestine. Parasit Vectors; 2020;1-8.

5. Ola-Fadunsin SD, Maizatul AM, Ibrahim AR, Amlizawathy A, Chandrawathani P, A JFF. Molecular Prevalence and Species Co-Infection of Bovine Haemoparasites in Peninsular Malaysia. Malaysian J Vet Res. 2017;8:13-22.

6. Hayashida, K., Umemiya-Shirafuji, R., Sivakumar, T., Yamagishi, J., Suzuki, Y., Sugimoto, C., and Yokoyama N. Establishment of a mouse-tick infestation model for Theileria orientalis and analysis of its transcriptome. Int J Parasitol. 2018;48:985-924.

7. Mijares A, Vivas J, Abad C, Betancourt M, Piñero S, Proverbio F, et al. Trypanosoma evansi: Effect of experimental infection on the osmotic fragility, lipid peroxidation $\quad$ and calcium-ATPase activity of rat red blood cells. Exp Parasitol; 2010;124:301-5.

8. Shebish E, Vemulapalli R, Oseto C. Prevalence and molecular detection of Anaplasma marginale, Babesia bovis and Babesia bigemina in cattle from Puntarenas Province, Costa Rica. Vet Parasitol. 2012;188:164-7.

9. Bilgiç HB, Karagenç T, Simuunza M, Shiels B, Tait A, Eren H. Development of a multiplex PCR assay for simultaneous detection of Theileria annulata, Babesia bovis and Anaplasma marginale in cattle. Exp Parasitol. 2013;133:222-9.

10. Li Y, Chen Z, Liu Z, Liu J, Yang J, Li Q, et al. Molecular identification of Theileria parasites of northwestern Chinese Cervidae. Parasit Vectors. 2014;7:1-7.

11. Cao, S., Zhang, S., Jia, L., Xue, S., Yu, L., Kamyingkird, K., Moumouni, P.F., Moussa, A.A., Zhou, M., Zhang, Y., Terkawi, M.A., Masatani, T., Nishikawa, Y. \& Xuan X. Molecular detection of Theileria species in sheep from northern China. J Vet Med Sci. 2013;75:1227-30.

12. Liu, M.M., Jia, L.J., Cao, S.N., Adjou Moumouni, P.F., Jirapattharasate, C., Wang, G.B., Gao Y, Guo, H.P., Zhou, M., Yu, L.Z., Xue, S.J. and Xuan XN. Molecular Detection of Theileria species in Cattle from Jilin Province, China. Trop Biomed. 2017;34:598-606.

13. Amer S, Ryu O, Tada C, Fukuda Y, Inoue N, Nakai Y. Molecular identification and phylogenetic analysis of Trypanosoma evansi from dromedary camels (Camelus dromedarius) in Egypt, a pilot study. Acta Trop. 2011;117:39-46.

14. Holland, W.G., My, L.N., Dung, T.V., Thanh, N.G., Tam, P.T., Vercruysse, J. G. The influence of T. evansi infection on the immunoresponsiveness of experimentally infected water buffaloes. Vet Parasitol. 2001;102:225-34.

15. Neimark H, Kocan KM. The cell wall-less rickettsia Eperythrozoon wenyonii is a Mycoplasma. FEMS Microbiol Lett. 1997;156:287-91.

16. Messick J. Hemotrophic mycoplasmas (hemoplasmas): a review and new insights into pathogenic potential. Vet Clin Pathol. 2004;33:2-13.

17. Tagawa M, Matsumoto K, Inokuma H. Molecular detection of Mycoplasma wenyonii "Candidatus Mycoplasma haemobos" in cattle in Hokkaido, Japan. Vet Microbiol. 2008;132:177-80. 
18. Palomar, A. M., Portillo, A., Santibanez, P., Mazuelas, D., Roncero, L., Garcia- Alvarez, L., Santibanez, S., Gutierrez, O., \& Oteo JA. Detection of tick-borne Anaplasma bovis, Anaplasma phagocytophilum and Anaplasma centrale in Spain. Med Vet Entomol. 2015;29:349-53.

19. Rjeibi MR, Ayadi O, Rekik M, Gharbi M. Molecular survey and genetic characterization of Anaplasma centrale , A . marginale and A . bovis in cattle from Algeria. Transbound Emerg Dis. 2017;1-9.

20. Dyachenko V, Pantchev N, Balzer HJ, Meyersen A SR. First case of Anaplasma platys infection in a dog from Croatia. Parasit Vectors. 2012;5:49.

21. Kocan KM, Fuente J De. The genus Anaplasma: new challenges after reclassification Introduction and current and importance as pathogens Antigenic diversity and epidemiology. Rev Sci Tech. 2015;34:577-86.

22. Chien NTH, Nguyen TL, Bui KL, Nguyen T Van, Le TH. Anaplasma marginale and A. Platys characterized from dairy and indigenous cattle and dogs in northern Vietnam. Korean J Parasitol. 2019;57:43-8.

23. Jalali SM, Ghorbanpour M, Jalali MR, Rasooli A, Safaie P, Norvej F. Occurrence and potential causative factors of immune-mediated hemolytic anaemia in cattle and river buffaloes. Vet Res Forum. 2018;9:7-12.

24. Hassan MA, Liu J, Rashid M, Iqbal N, Guan G, Yin H, et al. Molecular survey of piroplasm species from selected areas of China and Pakistan. Parasites and Vectors. Parasites \& Vectors; 2018;11:1-7.

25. Kho KL, Amarajothi ADG, Koh FX, Panchadcharam C, Nizamuddin Q, Nizam H, et al. Veterinary Parasitology: Regional Studies and Reports The fi rst molecular survey of theileriosis in Malaysian cattle, sheep and goats. Vet Parasitol Reg Stud Reports 2017;10:149-53.

26. Sugimoto, C., Fujisaki K. Theileria. In: McKeever DD, editor. Theileria. Boston, London: Kluwer Academic Publishers; 2002. p. 93-106.

27. Gebrekidan H, Gasser RB, Baneth G, Yasur-Landau D, Nachum-Biala Y, Hailu A, et al. Molecular characterization of Theileria orientalis from cattle in Ethiopia. Ticks Tick Borne Dis 2016;7:742-7.

28. Park J, Han Y, Han D, Chae J, Chae J, Yu D, et al. Genetic characterization of Theileria orientalis from cattle in the Republic of Korea. Parasitol Res. Parasitology Research; 2017;449-54.

29. Mans BJ, Pienaar R, Latif AA. A review of Theileria diagnostics and epidemiology. Int J Parasitol Parasites 2015;4:104-18.

30. Hayashida K, Kajino K, Hattori M, Wallace M, Morrison I, Greene MI, et al. MDM2 regulates a novel form of incomplete neoplastic transformation of Theileria parva infected lymphocytes. Exp Mol Pathol 2013;94:228-38.

31. Bai, Q., Liu, G., Yin, H., Zhao, Q., Liu, D., Ren, J., Li X. Theileria sinensis sp nov: a new species of bovine Theileria-molecular taxonomic studies. Xu Mu Shou Yi Xue Bao. 2002;33:185-90.

32. Roland L, Drillich M, Iwersen M. Hematology as a diagnostic tool in bovine medicine. J Vet Diagnostic Investig. 2014;26:592-8.

33. Roland L, Drillich M, Iwersen M. Hematology as a diagnostic tool in bovine medicine. J Vet Diagnostic Investig 2014;26:592-8

34. Ayadi O, Gharbi M, Benchikh-Elfegoun MC. Haematological and biochemical indicators of tropical theileriosis diseased cattle in wilaya of Sétif (North East Algeria). J Parasit Dis. 2017;41:538-42.

35. George N, Bhandari V, Reddy DP SP. Emergence of new genotype and diversity of Theileria orientalis parasites from bovines in India. Infect Genet Evol. 2015;36:27-34.

36. Khan, I. A., Khan, A., Hussain, A., Raiz, A., Aziz A. Hemato-Biochemical alterations in cross bred cattle affected with bovine Theileriosis in semi arid zone. Pak Vet J. 2011;31:137-40.

37. Igbokwe NA, Ojo NA, Igbokwe IO. Effects of sex and age on the osmotic stability of Sahel goat erythrocytes. Comp Clin Path. 2016;25:15-22.

38. Pati S, Panda SK, Behera PC, Panda MR. Assessment of Erythrocyte Osmotic Fragility in. 2017;6:1560-8.

39. Ariff, O.M., Sharifah, N.Y., Hafidz AW. Status of beef industry of Malaysia. Malaysian Soc Anim Prod. 2015;18:1-21.

40. Faulkner, W.R., King, J.W. Manual of Clinical Laboratory Procedures. Cleaveland, USA: Chemical Rubber Company; 1970.

41. Oyewale JO. Effects of temperature and pH on osmotic fragility of erythrocytes of the domestic fowl (Gallus domesticus) and guineafowl (Numida meleagris). Res Vet Sci. 1992;52:1-4.

42. Parola P, Roux V, Camicas JL, Baradji I, Brouqui P, Raoult D. Detection of ehrlichiae in African ticks by polymerase chain reaction. Trans R Soc Trop Med Hyg. 2000;94:707-8.

43. Sogin M L. Amplification of ribosomal RNA genes for molecular evolution studies. In: PCR protocols: a guide to methods and applications. Innis MA, Gelfand DH, Sninsky JJ, White TJ, editors. New York: Academic Press; 1990. p. 307-14. 
44. Su QL, Song HQ, Lin RQ, Yuan ZG, Yang JF, Zhao GH, et al. The detection of "Candidatus Mycoplasma haemobos" in cattle and buffalo in China. Trop Anim Health Prod. 2010;42:1805-8.

45. Shkap V, Leibovitz B, Krigel Y, Molad T, Fish L, Mazuz M, et al. Concomitant infection of cattle with the vaccine strain Anaplasma marginale ss centrale and field strains of A. marginale. Vet Microbiol. 2008;130:277-84.

46. Ota N, Mizuno D, Kuboki N, Igarashi I, Nakamura Y, Yamashina H, et al. Epidemiological survey of Theileria orientalis infection in grazing cattle in the eastern part of Hokkaido, Japan. J Vet Med Sci. 2009;71:937-44.

47. Claes F, Radwanska M, Urakawa T, Majiwa PAO, Goddeeris B, Büscher P. Variable surface glycoprotein RoTat 1.2 PCR as a specific diagnostic tool for the detection of Trypanosoma evansi infections. Kinetoplastid Biol Dis. 2004;3:1-6.

48. Kumar S, Stecher G, Li M, Knyaz C, Tamura K. MEGA X: Molecular evolutionary genetics analysis across computing platforms. Mol Biol Evol. 2018;35:1547-9.

49. Nei M. and Kumar S. Molecular Evolution and Phylogenetics. New York: Oxford University Press; 2000.

50. Shehu, S.A., Ibrahim, N.D.G., Esievo, K.A.N. \& Mohammed G. Role of erythrocyte surface sialic acid inducing anaemia in Savannah Brown bucks experimentally infected with Trypanosoma evansi. Veterenarski Arh. 2006;26:521-30.

51. Naessens J. Bovine trypanotolerance: a natural ability to prevent severe anaemia and haemophagocytic syndrome? Int J Parasitol. 2006;36:521-8.

52. Stockham, S. L. and Scott MA. Fundamentals of Veterinary Clinical Pathology. 2nd ed. lowa, USA: Blackwell Publishing; 2008.

53. Jain S, Gautam V, Naseem S. Acute-phase proteins: As diagnostic tool. J Pharm Bioallied Sci. 2011;3:118-27.

54. Singh A, Singh J, Grewal AS BR. Studies on some blood parameters of crossbred calves with experimental Theileria annulata infection. Vet Res Commun. 2001;25:289-300.

55. Grimes CN, Fry MM. Nonregenerative Anaemia: Mechanisms of Decreased or Ineffective Erythropoiesis. Vet Pathol. 2015;52:298311.

56. Brockus CW. Duncan and Prasse's veterinary laboratory medicine: clinical pathology. In: Latimer KS, editor. Duncan Prasse's Vet Lab Med Clin Pathol. 5th ed. Chichester, UK: Wiley; 2011. p. 3-44.

57. Ashuma, Sharma A, Singla L Das, Kaur P, Bal MS, Batth BK, et al. Prevalence and haemato-biochemical profile of Anaplasma marginale infection in dairy animals of $\quad$ Punjab (India). Asian Pac J Trop Med 2013;6:139-44.

58. Kerr MG. Veterinary Laboratory Medicine. 2nd ed. Ames, lowa: Blackwell Science Limited; 2002.

59. Webb JL, KS L. Duncan and Prasse's veterinary laboratory medicine: clinical pathology. In: Latimer KS, editor. Duncan Prasse's Vet Lab Med. 5th ed. Chichester, UK: Wiley; 2011. p. 45-82.

60. Burton AG, Harris LA, Owens SD, Jandrey KE. The prognostic utility of degenerative left shifts in dogs. J Vet Intern Med. 2013;27:1517-22.

61. Antwi-Baffour S, Quao E, Kyeremeh R, Mahmood SA. Prolong Storage of Blood in EDTA Has an Effect on the Morphology and Osmotic Fragility of Erythrocytes. Int J Biomed Sci Eng 2013;1:20.

62. Somu Y, Mani S, Muthusamy R, Mani S, Thangamani A, Konappan J, et al. Haemato- biochemical and electrolyte alterations in naturally occurring Theileria Associated Bovine Anaemia (Taba). J Anim Heal Prod 2017;5:64-7.

63. Takeet MI, Adeleye Al, Adebayo OO, \& Akande FA. Haematology and serum biochemical alteration in stress induced equine theileriosis. A case report. Sci World J. 2009;4:19-21.

\section{Tables}


Table 1

Genus-specific primers, thermocyclic conditions and amplicon size of the various genes used for the detection and amplification of cattle blood pathogens. Thermocyclic conditions include initial denaturing (ID), denaturing (D), annealing (A), extension (E), and final extension

(FE).

\begin{tabular}{|c|c|c|c|c|c|}
\hline $\begin{array}{l}\text { Blood } \\
\text { Pathogens }\end{array}$ & Gene & $\begin{array}{l}\text { Genus-specific Primer Sequences }\left(5^{\prime}-3^{\prime}\right) \text { Forward }(F) \\
\text { and Reverse }(R)\end{array}$ & $\begin{array}{l}\text { Thermocyclic } \\
\text { condition }\end{array}$ & $\begin{array}{l}\text { Base pair } \\
\text { (bp) }\end{array}$ & References \\
\hline $\begin{array}{l}\text { Anaplasma } \\
\text { species }\end{array}$ & 16SrRNA & $\begin{array}{l}\text { EHR16SD - GGTACCYACAGAAGAAGTCC } \\
\text { EHR 16SR -TAGCACTCATCGTTTACAGC }\end{array}$ & $\begin{array}{l}\text { ID: } 95^{\circ} \mathrm{C} / 5 \text { min } \\
\text { D: } 95^{\circ} \mathrm{C} / 30 \text { secs } \\
\text { A: } 55^{\circ} \mathrm{C} / 30 \text { secs } \\
\text { E: } 72^{\circ} \mathrm{C} / 90 \text { secs } \\
\text { No of cycles: } 40 \\
\text { FE: } 72^{\circ} \mathrm{C} / 5 \text { min }\end{array}$ & 345 & [42] \\
\hline $\begin{array}{l}\text { Theileria } \\
\text { species }\end{array}$ & 18SrRNA & $\begin{array}{l}\text { F- ACCTGGTTGATCCTGCCAG } \\
\text { R-GATCCTTCGCAGGTTCACCTAC }\end{array}$ & $\begin{array}{l}\text { ID: } 94^{\circ} \mathrm{C} / 5 \mathrm{~min} \\
\mathrm{D}: 94^{\circ} \mathrm{C} / 30 \mathrm{secs} \\
\mathrm{A}: 60^{\circ} \mathrm{C} / 30 \mathrm{secs} \\
\mathrm{E}: 72^{\circ} \mathrm{C} / 1 \mathrm{~min} \\
\text { No of cycles: } 40 \\
\text { FE: } 72^{\circ} \mathrm{C} / 5 \mathrm{~min}\end{array}$ & 1750 & [43] \\
\hline $\begin{array}{l}\text { Mycoplasma } \\
\text { species }\end{array}$ & 16SrRNA & $\begin{array}{l}\text { F-GGGAGCAAACAGGATTAGATACCCT } \\
\text { R-TGCACCATCTGTCACTCTGTTAACCTC }\end{array}$ & $\begin{array}{l}\text { ID: } 94^{\circ} \mathrm{C} / 5 \mathrm{~min} \\
\mathrm{D}: 94^{\circ} \mathrm{C} / 30 \mathrm{secs} \\
\text { A: } 55^{\circ} \mathrm{C} / 30 \mathrm{secs} \\
\mathrm{E}: 72^{\circ} \mathrm{C} \\
/ 1 \text { min } 50 \text { secs } \\
\text { No of cycles: } 40 \\
\text { FE: } 72^{\circ} \mathrm{C} / 10 \mathrm{~min}\end{array}$ & 280 & [44] \\
\hline
\end{tabular}

Table 2

Species-specific primers, thermocyclic conditions and amplicon size of the various genes used for the detection and PCR amplification of cattle blood pathogens. Thermocyclic conditions include initial denaturing (ID), denaturing (D), annealing (A), extension (E), and final extension (FE).

\begin{tabular}{|c|c|c|c|c|c|}
\hline Blood Pathogens & Gene & $\begin{array}{l}\text { Species-specific Primer Sequences }\left(5^{\prime}-3^{\prime}\right) \\
\text { Forward }(F) \text { and Reverse }(R)\end{array}$ & $\begin{array}{l}\text { Thermocyclic } \\
\text { condition }\end{array}$ & $\begin{array}{l}\text { Base } \\
\text { pair (bp) }\end{array}$ & References \\
\hline Anaplasma marginale & msp4 & $\begin{array}{l}\text { F- CATCTCCCATGAGTCACGAAGTGGC } \\
\text { R- GCTGAACAGGAATCTTGCTCCAAG }\end{array}$ & $\begin{array}{l}\text { ID: } 95^{\circ} \mathrm{C} / 5 \mathrm{~min} \\
\mathrm{D}: 95^{\circ} \mathrm{C} / 1 \mathrm{~min} \\
\mathrm{~A}: 65^{\circ} \mathrm{C} / 2 \mathrm{~min} \\
\mathrm{E}: 72^{\circ} \mathrm{C} / 1 \mathrm{~min} \\
\text { No of cycles: } 40 \\
\text { FE: } 72^{\circ} \mathrm{C} / 10 \mathrm{~min}\end{array}$ & 761 & [45] \\
\hline Theileria orientalis & MPSP & $\begin{array}{l}\text { F- CTTTGCCTAGGATACTTCCT } \\
\text { R-ACGGCAAGTGGTGAGAACT }\end{array}$ & $\begin{array}{l}\text { ID: } 94^{\circ} \mathrm{C} / 4 \min \\
\text { D: } 94^{\circ} \mathrm{C} / 1 \mathrm{~min} \\
\text { A: } 63^{\circ} \mathrm{C} / 1 \mathrm{~min} \\
\mathrm{E}: 72^{\circ} \mathrm{C} / 1 \mathrm{~min} \\
\text { No of cycles: } 40 \\
\text { FE: } 722^{\circ} \mathrm{C} / 7 \mathrm{~min}\end{array}$ & 776 & [46] \\
\hline Trypanosoma evansi & $\begin{array}{l}\text { RoTaT } \\
1.2\end{array}$ & $\begin{array}{l}\text { F- 5'-GCG GGG TGT TTA AAG CAA TA-3' } \\
\text { R- 5'-ATT AGT GCT GCG TGT GTT CG-3' }\end{array}$ & $\begin{array}{l}\text { ID: } 94^{\circ} \mathrm{C} / 4 \min \\
\text { D: } 94^{\circ} \mathrm{C} / 1 \mathrm{~min} \\
\text { A: } 59^{\circ} \mathrm{C} / 1 \mathrm{~min} \\
\mathrm{E}: 72^{\circ} \mathrm{C} / 1 \mathrm{~min} \\
\text { No of cycles:40 } \\
\text { FE: } 72^{\circ} \mathrm{C} / 5 \mathrm{~min}\end{array}$ & 205 & [47] \\
\hline $\begin{array}{l}\text { Candidatus } \\
\text { Mycoplasma haemobos }\end{array}$ & 16SrRNA & $\begin{array}{l}\text { F- GAGTTAGTTATTAAAGCTTTAT } \\
\text { R- ATTCATGAGGTACTATCAGTTG }\end{array}$ & $\begin{array}{l}\text { ID: } 94^{\circ} \mathrm{C} / 5 \mathrm{~min} \\
\mathrm{D}: 94^{\circ} \mathrm{C} \\
/ 30 \mathrm{secs} \\
\mathrm{A}: 55^{\circ} \mathrm{C} \\
/ 30 \mathrm{secs} \\
\mathrm{E}: 72^{\circ} \mathrm{C} / 30 \mathrm{secs} \\
\text { No of cycles: } 40 \\
\mathrm{FE}: 72^{\circ} \mathrm{C} / 7 \mathrm{~min}\end{array}$ & 279 & [44] \\
\hline
\end{tabular}


Table 3

Erythrocytic parameters of KK X Brahman cattle naturally infected by blood pathogens

\begin{tabular}{|c|c|c|c|c|c|c|c|c|c|}
\hline $\begin{array}{l}\text { Haematological } \\
\text { Parameters }\end{array}$ & $\begin{array}{l}\text { T. } \\
\text { evansi } \\
\text { infected } \\
\text { cattle }\end{array}$ & $\begin{array}{l}\text { Candidatus } \\
\text { M. } \\
\text { haemobos } \\
\text { infected } \\
\text { cattle }\end{array}$ & $\begin{array}{l}\text { T. } \\
\text { sinensis } \\
\text { infected } \\
\text { cattle }\end{array}$ & $\begin{array}{l}\text { T. } \\
\text { orientalis } \\
+\mathrm{A} \text {. } \\
\text { marginale } \\
\text { infected } \\
\text { cattle }\end{array}$ & $\begin{array}{l}\text { A. } \\
\text { platys + } \\
\text { T. } \\
\text { sinensis }\end{array}$ & $\begin{array}{l}\text { T. } \\
\text { sinensis + } \\
\text { C. M. } \\
\text { haemobos } \\
\text { infected } \\
\text { cattle }\end{array}$ & $\begin{array}{l}\text { T. } \\
\text { orientalis } \\
+\mathrm{T} \text {. } \\
\text { sinensis } \\
\text { infected } \\
\text { cattle }\end{array}$ & $\begin{array}{l}\text { C. M. } \\
\text { haemobos } \\
+\mathrm{T} \text {. } \\
\text { sinensis + } \\
\text { A. } \\
\text { marginale } \\
\text { infected } \\
\text { cattle }\end{array}$ & $\begin{array}{l}\text { Reference } \\
\text { value* }\end{array}$ \\
\hline PCV (L/L) & $\begin{array}{l}0.20 \pm \\
0.01^{a}\end{array}$ & $\begin{array}{l}0.32 \pm \\
0.04^{b}\end{array}$ & $\begin{array}{l}0.23 \pm \\
0.01^{\mathrm{a}}\end{array}$ & $\begin{array}{l}0.33 \pm \\
0.02^{b}\end{array}$ & $\begin{array}{l}0.32 \pm \\
0.06^{b}\end{array}$ & $\begin{array}{l}0.33 \pm \\
0.01^{b}\end{array}$ & $\begin{array}{l}0.34 \pm \\
0.02^{b}\end{array}$ & $\begin{array}{l}0.30 \pm \\
0.02^{b}\end{array}$ & $\begin{array}{l}0.24- \\
0.46\end{array}$ \\
\hline $\begin{array}{l}\text { RBC count } \\
\left(x 10^{12} / \mathrm{L}\right)\end{array}$ & $\begin{array}{l}3.03 \pm \\
0.03^{a}\end{array}$ & $\begin{array}{l}6.47^{ \pm} \\
0.38^{b}\end{array}$ & $\begin{array}{l}3.86 \pm \\
0.37^{a}\end{array}$ & $\begin{array}{l}5.83 \pm \\
0.45^{\mathrm{b}}\end{array}$ & $\begin{array}{l}4.78 \pm \\
0.45^{a}\end{array}$ & $\begin{array}{l}7.05 \pm \\
0.41^{\mathrm{b}}\end{array}$ & $\begin{array}{l}6.47 \pm \\
0.52^{b}\end{array}$ & $\begin{array}{l}5.67 \pm \\
0.44^{\mathrm{b}}\end{array}$ & $5-10$ \\
\hline $\begin{array}{l}\text { Haemoglobin } \\
(\mathrm{g} / \mathrm{L})\end{array}$ & $\begin{array}{l}62.50 \pm \\
0.50^{a}\end{array}$ & $\begin{array}{l}84.33 \pm \\
0.50^{\text {bcd }}\end{array}$ & $\begin{array}{l}67.88 \pm \\
2.82^{a b}\end{array}$ & $\begin{array}{l}95.63 \pm \\
4.84 \mathrm{~cd}\end{array}$ & $\begin{array}{l}78.00 \pm \\
0.00^{\mathrm{b}}\end{array}$ & $\begin{array}{l}103.00 \pm \\
3.78^{d}\end{array}$ & $\begin{array}{l}87.00 \pm \\
5.99^{\mathrm{bcd}}\end{array}$ & $\begin{array}{l}82.00 \pm \\
2.35^{\mathrm{bc}}\end{array}$ & $80-150$ \\
\hline $\operatorname{MCV}(\mathrm{fl})$ & $\begin{array}{l}66.09 \pm \\
2.76^{b}\end{array}$ & $\begin{array}{l}48.68 \pm \\
5.54^{a}\end{array}$ & $\begin{array}{l}54.56 \pm \\
3.28^{a b}\end{array}$ & $\begin{array}{l}58.63 \pm \\
3.43^{\mathrm{ab}}\end{array}$ & $\begin{array}{l}68.79 \pm \\
3.14^{b}\end{array}$ & $\begin{array}{l}49.75 \pm \\
2.53^{a}\end{array}$ & $\begin{array}{l}54.77 \pm \\
3.83^{\mathrm{ab}}\end{array}$ & $\begin{array}{l}54.23 \pm \\
7.01^{\mathrm{ab}}\end{array}$ & $40-60$ \\
\hline $\mathrm{MCHC}(\mathrm{g} / \mathrm{L})$ & $\begin{array}{l}328.00 \\
\pm 4.00\end{array}$ & $\begin{array}{l}339.75 \pm \\
6.32\end{array}$ & $\begin{array}{l}293.03 \\
\pm 5.79\end{array}$ & $\begin{array}{l}329.67 \pm \\
4.26\end{array}$ & $\begin{array}{l}321.00 \\
\pm 3.00\end{array}$ & $\begin{array}{l}330.83 \pm \\
5.75\end{array}$ & $\begin{array}{l}329.78 \pm \\
4.26\end{array}$ & $\begin{array}{l}330.83 \pm \\
5.76\end{array}$ & $300-360$ \\
\hline RDW (\%) & $\begin{array}{l}24.90 \pm \\
0.10^{\mathrm{b}}\end{array}$ & $\begin{array}{l}18.90 \pm \\
0.91^{a}\end{array}$ & $\begin{array}{l}23.49 \pm \\
1.93^{b}\end{array}$ & $\begin{array}{l}18.79 \pm \\
0.72^{\mathrm{a}}\end{array}$ & $\begin{array}{l}25.90 \pm \\
1.18^{b}\end{array}$ & $\begin{array}{l}20.91 \pm \\
0.62^{b}\end{array}$ & $\begin{array}{l}21.04 \pm \\
0.78^{b}\end{array}$ & $\begin{array}{l}22.93 \pm \\
2.54^{b}\end{array}$ & $20-35.9$ \\
\hline $\begin{array}{l}\text { Plasma } \\
\text { proteins (g/L) }\end{array}$ & $\begin{array}{l}109.00 \\
\pm 1.41^{b}\end{array}$ & $\begin{array}{l}86.25 \pm \\
5.07^{a}\end{array}$ & $\begin{array}{l}91.11 \pm \\
2.65^{\mathrm{a}}\end{array}$ & $\begin{array}{l}93.60 \pm \\
4.11^{a}\end{array}$ & $\begin{array}{l}95.00 \pm \\
5.00^{\mathrm{a}}\end{array}$ & $\begin{array}{l}95.35 \pm \\
3.10^{a}\end{array}$ & $\begin{array}{l}90.63 \pm \\
4.12^{a}\end{array}$ & $\begin{array}{l}91.33 \pm \\
3.13^{a}\end{array}$ & $60-80$ \\
\hline $\begin{array}{l}\text { Icteric index } \\
\text { (units) }\end{array}$ & $\begin{array}{l}50.00 \pm \\
0.00^{\mathrm{b}}\end{array}$ & $\begin{array}{l}5.00 \pm \\
0.00^{a}\end{array}$ & $\begin{array}{l}5.00 \pm \\
0.00^{a}\end{array}$ & $\begin{array}{l}5.00 \pm \\
0.00^{\mathrm{a}}\end{array}$ & $\begin{array}{l}5.00 \pm \\
0.00^{\mathrm{a}}\end{array}$ & $\begin{array}{l}5.00 \pm \\
0.00^{a}\end{array}$ & $\begin{array}{l}5.00 \pm \\
0.00^{a}\end{array}$ & $\begin{array}{l}5.00 \pm \\
0.00^{a}\end{array}$ & $<15$ \\
\hline $\begin{array}{l}\text { Platelets } \\
\text { (x 109/L) }\end{array}$ & $\begin{array}{l}321.50 \\
\pm 6.50^{a}\end{array}$ & $\begin{array}{l}392.00 \pm \\
2.36^{a}\end{array}$ & $\begin{array}{l}378.11 \\
\pm 7.42^{a}\end{array}$ & $\begin{array}{l}357.44 \pm \\
5.01^{a}\end{array}$ & $\begin{array}{l}420.00 \\
\pm 7.00^{b}\end{array}$ & $\begin{array}{l}458.72 \pm \\
6.59^{b}\end{array}$ & $\begin{array}{l}322.25 \pm \\
9.89^{a}\end{array}$ & $\begin{array}{l}600.33 \pm \\
8.61^{c}\end{array}$ & $100-800$ \\
\hline
\end{tabular}


Table 4

Leukocytic parameters of Kedah-Kelantan X Brahman cattle naturally infected by blood pathogens

\begin{tabular}{|c|c|c|c|c|c|c|c|c|c|}
\hline $\begin{array}{l}\text { Leukocytic } \\
\text { Parameters }\end{array}$ & $\begin{array}{l}\text { T. } \\
\text { evansi } \\
\text { infected } \\
\text { cattle }\end{array}$ & $\begin{array}{l}\text { Candidatus } \\
\text { M. } \\
\text { haemobos } \\
\text { infected } \\
\text { cattle }\end{array}$ & $\begin{array}{l}\text { T. } \\
\text { sinensis } \\
\text { infected } \\
\text { cattle }\end{array}$ & $\begin{array}{l}\text { T. } \\
\text { orientalis } \\
+\mathrm{A} \text {. } \\
\text { marginale } \\
\text { infected } \\
\text { cattle }\end{array}$ & $\begin{array}{l}\text { A. } \\
\text { platys + } \\
\text { T. } \\
\text { sinensis }\end{array}$ & $\begin{array}{l}\text { T. } \\
\text { sinensis + } \\
\text { C. M. } \\
\text { haemobos } \\
\text { infected } \\
\text { cattle }\end{array}$ & $\begin{array}{l}\mathrm{T} . \\
\text { orientalis } \\
+\mathrm{T} \text {. } \\
\text { sinensis } \\
\text { infected } \\
\text { cattle }\end{array}$ & $\begin{array}{l}\text { C. M. } \\
\text { haemobos } \\
+\mathrm{T} \text {. } \\
\text { sinensis + } \\
\text { A. } \\
\text { marginale } \\
\text { infected } \\
\text { cattle }\end{array}$ & $\begin{array}{l}\text { Reference } \\
\text { value* }\end{array}$ \\
\hline $\begin{array}{l}\text { WBC count } \\
\left(\times 10^{9} / \mathrm{L}\right)\end{array}$ & $\begin{array}{l}4.94 \pm \\
0.28\end{array}$ & $5.22 \pm 0.65$ & $\begin{array}{l}5.07 \pm \\
0.58\end{array}$ & $\begin{array}{l}4.97 \pm \\
0.93\end{array}$ & $\begin{array}{l}6.96 \pm \\
0.72\end{array}$ & $\begin{array}{l}6.75 \pm \\
0.59\end{array}$ & $\begin{array}{l}6.91 \pm \\
0.54\end{array}$ & $6.36 \pm 0.97$ & $4.2-12.0$ \\
\hline $\begin{array}{l}\text { Lymphocyte } \\
\left(x 10^{9} / \mathrm{L}\right)\end{array}$ & $\begin{array}{l}3.97 \pm \\
0.42\end{array}$ & $4.08 \pm 0.71$ & $\begin{array}{l}3.81 \pm \\
0.50\end{array}$ & $\begin{array}{l}3.66 \pm \\
0.52\end{array}$ & $\begin{array}{l}5.47 \pm \\
0.67\end{array}$ & $\begin{array}{l}5.88 \pm \\
0.52\end{array}$ & $\begin{array}{l}5.24 \pm \\
0.56\end{array}$ & $4.98 \pm 0.82$ & $2.5-7.5$ \\
\hline $\begin{array}{l}\text { Promyelocyte } \\
\left(\times 10^{9} / \mathrm{L}\right)\end{array}$ & $\begin{array}{l}0.00 \pm \\
0.00\end{array}$ & $0.00 \pm 0.00$ & $\begin{array}{l}0.01 \pm \\
0.00\end{array}$ & $\begin{array}{l}0.00 \pm \\
0.00\end{array}$ & $\begin{array}{l}0.03 \pm \\
0.01\end{array}$ & $\begin{array}{l}0.01 \pm \\
0.00\end{array}$ & $\begin{array}{l}0.00 \pm \\
0.00\end{array}$ & $0.01 \pm 0.01$ & 0 \\
\hline $\begin{array}{l}\text { Myelocyte } \\
\left(x 10^{9} / \mathrm{L}\right)\end{array}$ & $\begin{array}{l}0.12 \pm \\
0.07\end{array}$ & $0.15 \pm 0.09$ & $\begin{array}{l}0.20 \pm \\
0.06\end{array}$ & $\begin{array}{l}0.40 \pm \\
0.18\end{array}$ & $\begin{array}{l}0.16 \pm \\
0.02\end{array}$ & $\begin{array}{l}0.14 \pm \\
0.04\end{array}$ & $\begin{array}{l}0.34 \pm \\
0.13\end{array}$ & $0.08 \pm 0.05$ & 0 \\
\hline $\begin{array}{l}\text { Metamyelocyte } \\
\left(\times 10^{9} / \mathrm{L}\right)\end{array}$ & $\begin{array}{l}0.40 \pm \\
0.03^{b}\end{array}$ & $\begin{array}{l}0.22 \pm \\
0.08^{b}\end{array}$ & $\begin{array}{l}0.26 \pm \\
0.10^{\mathrm{b}}\end{array}$ & $\begin{array}{l}0.20 \pm \\
0.04^{b}\end{array}$ & $\begin{array}{l}0.29 \pm \\
0.02\end{array}$ & $\begin{array}{l}0.12 \pm \\
0.03^{a}\end{array}$ & $\begin{array}{l}0.16 \pm \\
0.04^{a}\end{array}$ & $\begin{array}{l}0.15 \pm \\
0.08^{a}\end{array}$ & 0 \\
\hline Band $\left(x 10^{9} / \mathrm{L}\right)$ & $\begin{array}{l}0.27^{ \pm} \\
0.11^{\mathrm{b}}\end{array}$ & $\begin{array}{l}0.66 \pm \\
0.06^{a}\end{array}$ & $\begin{array}{l}0.34 \pm \\
0.08^{b}\end{array}$ & $\begin{array}{l}0.39 \pm \\
0.11^{b}\end{array}$ & $\begin{array}{l}0.25 \pm \\
0.06\end{array}$ & $\begin{array}{l}0.29 \pm \\
0.05^{b}\end{array}$ & $\begin{array}{l}0.52 \pm \\
0.14^{a}\end{array}$ & $0.85 \pm 0.07$ & $<0.2$ \\
\hline $\begin{array}{l}\text { Segmented } \\
\text { Neutrophil } \\
\left(\times 10^{9} / \mathrm{L}\right)\end{array}$ & $\begin{array}{l}0.18 \pm \\
0.04\end{array}$ & $0.11 \pm 0.02$ & $\begin{array}{l}0.11 \pm \\
0.02\end{array}$ & $\begin{array}{l}0.20 \pm \\
0.04\end{array}$ & $\begin{array}{l}0.27 \pm \\
0.16\end{array}$ & $\begin{array}{l}0.31 \pm \\
0.04\end{array}$ & $\begin{array}{l}0.31 \pm \\
0.08\end{array}$ & $0.29 \pm 0.11$ & $0.6-4.0$ \\
\hline $\begin{array}{l}\text { Eosinophil } \\
\left(x 10^{9} / \mathrm{L}\right)\end{array}$ & $\begin{array}{l}0.03 \pm \\
0.01^{a}\end{array}$ & $\begin{array}{l}0.31 \pm \\
0.17^{b}\end{array}$ & $\begin{array}{l}0.27^{ \pm} \\
0.11^{\mathrm{b}}\end{array}$ & $\begin{array}{l}0.78 \pm \\
0.04^{c}\end{array}$ & $\begin{array}{l}0.33^{ \pm} \\
0.21^{\mathrm{b}}\end{array}$ & $\begin{array}{l}0.50 \pm \\
0.05^{c}\end{array}$ & $\begin{array}{l}0.49 \pm \\
0.03^{c}\end{array}$ & $\begin{array}{l}0.57 \pm \\
0.02^{c}\end{array}$ & $0.05-2.4$ \\
\hline $\begin{array}{l}\text { Basophil } \\
\left(\times 10^{9} / \mathrm{L}\right)\end{array}$ & $\begin{array}{l}0.00 \pm \\
0.00^{a}\end{array}$ & $\begin{array}{l}0.05 \pm \\
0.02^{b}\end{array}$ & $\begin{array}{l}0.06 \pm \\
0.01^{\mathrm{b}}\end{array}$ & $\begin{array}{l}0.01^{ \pm} \\
0.01^{a}\end{array}$ & $\begin{array}{l}0.00 \pm \\
0.00^{a}\end{array}$ & $\begin{array}{l}0.00 \pm \\
0.00^{a}\end{array}$ & $\begin{array}{l}0.00 \pm \\
0.00^{a}\end{array}$ & $\begin{array}{l}0.03 \pm \\
0.02^{b}\end{array}$ & $<0.2$ \\
\hline $\begin{array}{l}\text { Monocyte } \\
\left(x 10^{9} / \mathrm{L}\right)\end{array}$ & $\begin{array}{l}0.10 \pm \\
0.01^{a}\end{array}$ & $\begin{array}{l}0.08 \pm \\
0.03^{a}\end{array}$ & $\begin{array}{l}0.44 \pm \\
0.11^{b}\end{array}$ & $\begin{array}{l}0.12 \pm \\
0.04^{a}\end{array}$ & $\begin{array}{l}0.11 \pm \\
0.05^{\mathrm{a}}\end{array}$ & $\begin{array}{l}0.20 \pm \\
0.05^{a}\end{array}$ & $\begin{array}{l}0.16 \pm \\
0.33^{a}\end{array}$ & $\begin{array}{l}0.15 \pm \\
0.02^{\mathrm{a}}\end{array}$ & $0.05-0.8$ \\
\hline
\end{tabular}


Table 5

Electrolytes and kidney function parameters of Kedah-Kelantan X Brahman cattle naturally infected by blood pathogens

\begin{tabular}{|c|c|c|c|c|c|c|c|c|c|}
\hline $\begin{array}{l}\text { Serum } \\
\text { biochemical } \\
\text { parameters }\end{array}$ & $\begin{array}{l}\text { T. } \\
\text { evansi } \\
\text { infected } \\
\text { cattle }\end{array}$ & $\begin{array}{l}\text { Candidatus } \\
\text { M. } \\
\text { haemobos } \\
\text { infected } \\
\text { cattle }\end{array}$ & $\begin{array}{l}\text { T. } \\
\text { sinensis } \\
\text { infected } \\
\text { cattle }\end{array}$ & $\begin{array}{l}\text { T. } \\
\text { orientalis } \\
+\mathrm{A} \text {. } \\
\text { marginale } \\
\text { infected } \\
\text { cattle }\end{array}$ & $\begin{array}{l}\text { A. } \\
\text { platys + } \\
\text { T. } \\
\text { sinensis } \\
\text { infected } \\
\text { cattle }\end{array}$ & $\begin{array}{l}\text { T. sinensis } \\
\text { + C. M. } \\
\text { haemobos } \\
\text { infected } \\
\text { cattle }\end{array}$ & $\begin{array}{l}\text { T. } \\
\text { orientalis } \\
+\mathrm{T} \text {. } \\
\text { sinensis } \\
\text { infected } \\
\text { cattle }\end{array}$ & $\begin{array}{l}\text { C. M. } \\
\text { haemobos + } \\
\text { sinensis + A. } \\
\text { marginale } \\
\text { infected } \\
\text { cattle }\end{array}$ & $\begin{array}{l}\text { Reference } \\
\text { value* }\end{array}$ \\
\hline $\begin{array}{l}\text { Sodium } \\
(\mathrm{mmol} / \mathrm{L})\end{array}$ & $\begin{array}{l}191.50 \\
\pm 6.50\end{array}$ & $\begin{array}{l}209.00 \pm \\
6.06\end{array}$ & $\begin{array}{l}187.22 \\
\pm 7.22\end{array}$ & $\begin{array}{l}187.56 \pm \\
6.20\end{array}$ & $\begin{array}{l}168.50 \\
\pm 7.19\end{array}$ & $\begin{array}{l}180.78 \pm \\
8.72\end{array}$ & $\begin{array}{l}179.89 \pm \\
6.93\end{array}$ & $\begin{array}{l}170.50 \pm \\
3.00\end{array}$ & $132-145$ \\
\hline $\begin{array}{l}\text { Potassium } \\
\text { (mmol/L) }\end{array}$ & $\begin{array}{l}6.15 \pm \\
0.05\end{array}$ & $6.50 \pm 0.58$ & $\begin{array}{l}5.86 \pm \\
0.19\end{array}$ & $\begin{array}{l}6.10 \pm \\
0.47\end{array}$ & $\begin{array}{l}5.20 \pm \\
1.20\end{array}$ & $5.76 \pm 0.24$ & $\begin{array}{l}5.57 \pm \\
0.29\end{array}$ & $5.25 \pm 0.39$ & $4.1-5.1$ \\
\hline $\begin{array}{l}\text { Chloride } \\
\text { (mmol/L) }\end{array}$ & $\begin{array}{l}126.50 \\
\pm 5.50^{\mathrm{ab}}\end{array}$ & $\begin{array}{l}150.50 \pm \\
4.45^{b}\end{array}$ & $\begin{array}{l}133.33 \\
\pm 6.15^{\mathrm{ab}}\end{array}$ & $\begin{array}{l}129.40 \pm \\
5.74^{\mathrm{ab}}\end{array}$ & $\begin{array}{l}117.50 \\
\pm 3.32^{\mathrm{a}}\end{array}$ & $\begin{array}{l}126.72 \pm \\
6.70^{a b}\end{array}$ & $\begin{array}{l}126.44 \pm \\
5.10^{\mathrm{ab}}\end{array}$ & $\begin{array}{l}118.00 \pm \\
9.58^{a}\end{array}$ & $85-105$ \\
\hline $\begin{array}{l}\text { Inorganic } \\
\text { phosphate } \\
(\mathrm{mmol} / \mathrm{L})\end{array}$ & $\begin{array}{l}2.75 \pm \\
0.05\end{array}$ & $2.35 \pm 0.40$ & $\begin{array}{l}2.38 \pm \\
0.17\end{array}$ & $\begin{array}{l}2.54 \pm \\
0.12\end{array}$ & $\begin{array}{l}2.65 \pm \\
0.65\end{array}$ & $2.82 \pm 0.15$ & $\begin{array}{l}2.73 \pm \\
0.15\end{array}$ & $2.68 \pm 0.27$ & $1.6-2.9$ \\
\hline $\begin{array}{l}\text { Creatinine } \\
(\mu \mathrm{mol} / \mathrm{L})\end{array}$ & $\begin{array}{l}182.00 \\
\pm 1.00^{c}\end{array}$ & $\begin{array}{l}104.75 \pm \\
6.87^{b}\end{array}$ & $\begin{array}{l}85.00 \pm \\
4.17^{a}\end{array}$ & $\begin{array}{l}104.30 \pm \\
3.60^{b}\end{array}$ & $\begin{array}{l}95.00 \pm \\
2.00^{\mathrm{a}}\end{array}$ & $\begin{array}{l}113.59 \pm \\
3.25^{b}\end{array}$ & $\begin{array}{l}104.57 \pm \\
4.11^{b}\end{array}$ & $\begin{array}{l}106.83 \pm \\
4.25^{b}\end{array}$ & $<176$ \\
\hline $\begin{array}{l}\text { Urea } \\
(\mathrm{mmol} / \mathrm{L})\end{array}$ & $\begin{array}{l}11.30 \pm \\
1.00^{\mathrm{b}}\end{array}$ & $\begin{array}{l}6.88 \pm \\
1.11^{\mathrm{a}}\end{array}$ & $\begin{array}{l}6.11 \pm \\
0.51^{a}\end{array}$ & $\begin{array}{l}7.24 \pm \\
0.54^{\mathrm{a}}\end{array}$ & $\begin{array}{l}8.40 \pm \\
0.30^{\mathrm{a}}\end{array}$ & $\begin{array}{l}7.94 \pm \\
0.26^{a}\end{array}$ & $\begin{array}{l}7.68 \pm \\
0.54^{\mathrm{a}}\end{array}$ & $7.25 \pm 0.48^{a}$ & $1.8-7.1$ \\
\hline
\end{tabular}


Table 6

Liver function test parameters Kedah-Kelantan X Brahman cattle naturally infected by blood pathogens

\begin{tabular}{|c|c|c|c|c|c|c|c|c|c|}
\hline $\begin{array}{l}\text { Serum } \\
\text { biochemical } \\
\text { parameters }\end{array}$ & $\begin{array}{l}\text { T. } \\
\text { evansi } \\
\text { infected } \\
\text { cattle }\end{array}$ & $\begin{array}{l}\text { Candidatus } \\
\text { M. } \\
\text { haemobos } \\
\text { infected } \\
\text { cattle }\end{array}$ & $\begin{array}{l}\text { T. } \\
\text { sinensis } \\
\text { infected } \\
\text { cattle }\end{array}$ & $\begin{array}{l}\text { T. } \\
\text { orientalis } \\
+\mathrm{A} \text {. } \\
\text { marginale } \\
\text { infected } \\
\text { cattle }\end{array}$ & $\begin{array}{l}\text { A. } \\
\text { platys + } \\
\text { T. } \\
\text { sinensis }\end{array}$ & $\begin{array}{l}\text { T. sinensis } \\
\text { + C. M. } \\
\text { haemobos } \\
\text { infected } \\
\text { cattle }\end{array}$ & $\begin{array}{l}\text { T. } \\
\text { orientalis } \\
+\mathrm{T} \text {. } \\
\text { sinensis } \\
\text { infected } \\
\text { cattle }\end{array}$ & $\begin{array}{l}\text { C. M. } \\
\text { haemobos } \\
+\mathrm{T} \text {. } \\
\text { sinensis + A. } \\
\text { marginale } \\
\text { infected } \\
\text { cattle }\end{array}$ & $\begin{array}{l}\text { Reference } \\
\text { value* }\end{array}$ \\
\hline $\operatorname{ALP}(\mathrm{U} / \mathrm{L})$ & $\begin{array}{l}351.00 \\
\pm 5.00^{d}\end{array}$ & $\begin{array}{l}54.00 \pm \\
6.35^{\mathrm{ab}}\end{array}$ & $\begin{array}{l}44.67 \pm \\
4.22^{a}\end{array}$ & $\begin{array}{l}57.50 \pm \\
6.97^{a b}\end{array}$ & $\begin{array}{l}51.00 \pm \\
5.14^{\mathrm{ab}}\end{array}$ & $\begin{array}{l}82.35 \pm \\
5.53^{b c}\end{array}$ & $\begin{array}{l}65.63 \pm \\
6.26^{\mathrm{abc}}\end{array}$ & $\begin{array}{l}88.50 \pm \\
6.07^{c}\end{array}$ & $50-100$ \\
\hline AST (U/L) & $\begin{array}{l}135.50 \\
\pm 2.50^{a}\end{array}$ & $\begin{array}{l}57.50 \pm \\
5.92^{\mathrm{b}}\end{array}$ & $\begin{array}{l}81.00 \pm \\
9.08^{b}\end{array}$ & $\begin{array}{l}68.10 \pm \\
9.17^{b}\end{array}$ & $\begin{array}{l}67.00 \pm \\
6.00^{\mathrm{b}}\end{array}$ & $\begin{array}{l}70.13 \pm \\
5.53^{b}\end{array}$ & $\begin{array}{l}71.13 \pm \\
5.18^{\mathrm{b}}\end{array}$ & $\begin{array}{l}62.40 \pm \\
7.69^{\mathrm{b}}\end{array}$ & $50-100$ \\
\hline Y-GT (U/L) & $\begin{array}{l}58.00 \pm \\
1.00^{\mathrm{b}}\end{array}$ & $\begin{array}{l}19.50 \pm \\
3.07^{a}\end{array}$ & $\begin{array}{l}17.11 \pm \\
2.90^{\mathrm{a}}\end{array}$ & $\begin{array}{l}31.20 \pm \\
6.06^{a}\end{array}$ & $\begin{array}{l}25.50 \pm \\
6.50^{a}\end{array}$ & $\begin{array}{l}20.38 \pm \\
2.95^{a}\end{array}$ & $\begin{array}{l}22.11 \pm \\
4.28^{a}\end{array}$ & $\begin{array}{l}29.20 \pm \\
3.71^{a}\end{array}$ & $<25$ \\
\hline $\begin{array}{l}\text { Total proteins } \\
(\mathrm{g} / \mathrm{L})\end{array}$ & $\begin{array}{l}92.40 \pm \\
1.80^{\mathrm{c}}\end{array}$ & $\begin{array}{l}76.93 \pm \\
4.05^{\mathrm{a}}\end{array}$ & $\begin{array}{l}75.29 \pm \\
2.95^{\mathrm{ab}}\end{array}$ & $\begin{array}{l}79.73 \pm \\
2.58^{\mathrm{b}}\end{array}$ & $\begin{array}{l}76.40 \pm \\
1.00^{\mathrm{ab}}\end{array}$ & $\begin{array}{l}76.17 \pm \\
1.68^{\mathrm{ab}}\end{array}$ & $\begin{array}{l}78.06 \pm \\
2.80^{b}\end{array}$ & $\begin{array}{l}76.13 \pm \\
2.06^{\mathrm{ab}}\end{array}$ & $55-75$ \\
\hline $\begin{array}{l}\text { Albumin } \\
(\mathrm{g} / \mathrm{L})\end{array}$ & $\begin{array}{l}21.75 \pm \\
0.65^{a}\end{array}$ & $\begin{array}{l}27.95 \pm \\
1.35^{\mathrm{b}}\end{array}$ & $\begin{array}{l}30.46 \pm \\
0.99^{b}\end{array}$ & $\begin{array}{l}31.52 \pm \\
0.80^{\mathrm{b}}\end{array}$ & $\begin{array}{l}32.90 \pm \\
3.40^{\mathrm{b}}\end{array}$ & $\begin{array}{l}32.62 \pm \\
0.82^{b}\end{array}$ & $\begin{array}{l}33.67 \pm \\
1.19^{b}\end{array}$ & $\begin{array}{l}32.30 \pm \\
2.03^{b}\end{array}$ & $25-40$ \\
\hline $\begin{array}{l}\text { Globulin } \\
(\mathrm{g} / \mathrm{L})\end{array}$ & $\begin{array}{l}70.65 \pm \\
1.15^{\mathrm{b}}\end{array}$ & $\begin{array}{l}48.98 \pm \\
2.71^{a}\end{array}$ & $\begin{array}{l}44.83 \pm \\
2.57^{a}\end{array}$ & $\begin{array}{l}48.21 \pm \\
2.11^{a}\end{array}$ & $\begin{array}{l}43.50 \pm \\
2.40^{a}\end{array}$ & $\begin{array}{l}43.56 \pm \\
1.54^{a}\end{array}$ & $\begin{array}{l}44.39 \pm \\
2.42^{a}\end{array}$ & $\begin{array}{l}43.83 \pm \\
1.57^{a}\end{array}$ & $27-45$ \\
\hline A: G (Unit) & $\begin{array}{l}0.31 \pm \\
0.01^{a}\end{array}$ & $\begin{array}{l}0.72 \pm \\
0.02^{b}\end{array}$ & $\begin{array}{l}0.70 \pm \\
0.04^{b}\end{array}$ & $\begin{array}{l}0.67 \pm \\
0.03^{b}\end{array}$ & $\begin{array}{l}0.84 \pm \\
0.14^{b}\end{array}$ & $\begin{array}{l}0.75 \pm \\
0.21^{b}\end{array}$ & $\begin{array}{l}0.73 \pm \\
0.04^{b}\end{array}$ & $0.76 \pm 0.07^{b}$ & $0.8-1.2$ \\
\hline $\begin{array}{l}\text { Total bilirubin } \\
(\mu \mathrm{mol} / \mathrm{L})\end{array}$ & $\begin{array}{l}30.30 \pm \\
0.50^{\mathrm{b}}\end{array}$ & $\begin{array}{l}5.05 \pm \\
0.93^{a}\end{array}$ & $\begin{array}{l}9.27 \pm \\
1.57^{a}\end{array}$ & $\begin{array}{l}8.03 \pm \\
1.29^{a}\end{array}$ & $\begin{array}{l}5.30 \pm \\
0.01^{a}\end{array}$ & $\begin{array}{l}9.03 \pm \\
1.04^{\mathrm{a}}\end{array}$ & $\begin{array}{l}7.37 \pm \\
0.81^{a}\end{array}$ & $7.88 \pm 1.51^{a}$ & $1.7-27.2$ \\
\hline $\begin{array}{l}\text { Conjugated } \\
\text { bilirubin } \\
(\mu \mathrm{mol} / \mathrm{L})\end{array}$ & $\begin{array}{l}8.50 \pm \\
0.20^{b}\end{array}$ & $\begin{array}{l}2.23 \pm \\
0.44^{a}\end{array}$ & $\begin{array}{l}3.58 \pm \\
0.54^{a}\end{array}$ & $\begin{array}{l}3.40 \pm \\
0.47^{a}\end{array}$ & $\begin{array}{l}2.30 \pm \\
0.30^{a}\end{array}$ & $\begin{array}{l}3.17 \pm \\
0.27^{a}\end{array}$ & $\begin{array}{l}2.75 \pm \\
0.36^{a}\end{array}$ & $3.18 \pm 0.51^{a}$ & $<10.2$ \\
\hline $\begin{array}{l}\text { Unconjugated } \\
\text { bilirubin } \\
(\mu \mathrm{mol} / \mathrm{L})\end{array}$ & $\begin{array}{l}21.80 \pm \\
0.30^{b}\end{array}$ & $\begin{array}{l}2.83 \pm \\
0.53^{a}\end{array}$ & $\begin{array}{l}5.69 \pm \\
1.05^{\mathrm{a}}\end{array}$ & $\begin{array}{l}4.63 \pm \\
0.85^{a}\end{array}$ & $\begin{array}{l}3.00 \pm \\
0.30^{\mathrm{a}}\end{array}$ & $\begin{array}{l}4.83 \pm \\
0.50^{\mathrm{a}}\end{array}$ & $\begin{array}{l}4.61 \pm \\
0.48^{a}\end{array}$ & $4.70 \pm 1.03^{a}$ & $<10.2$ \\
\hline
\end{tabular}

\section{Figures}




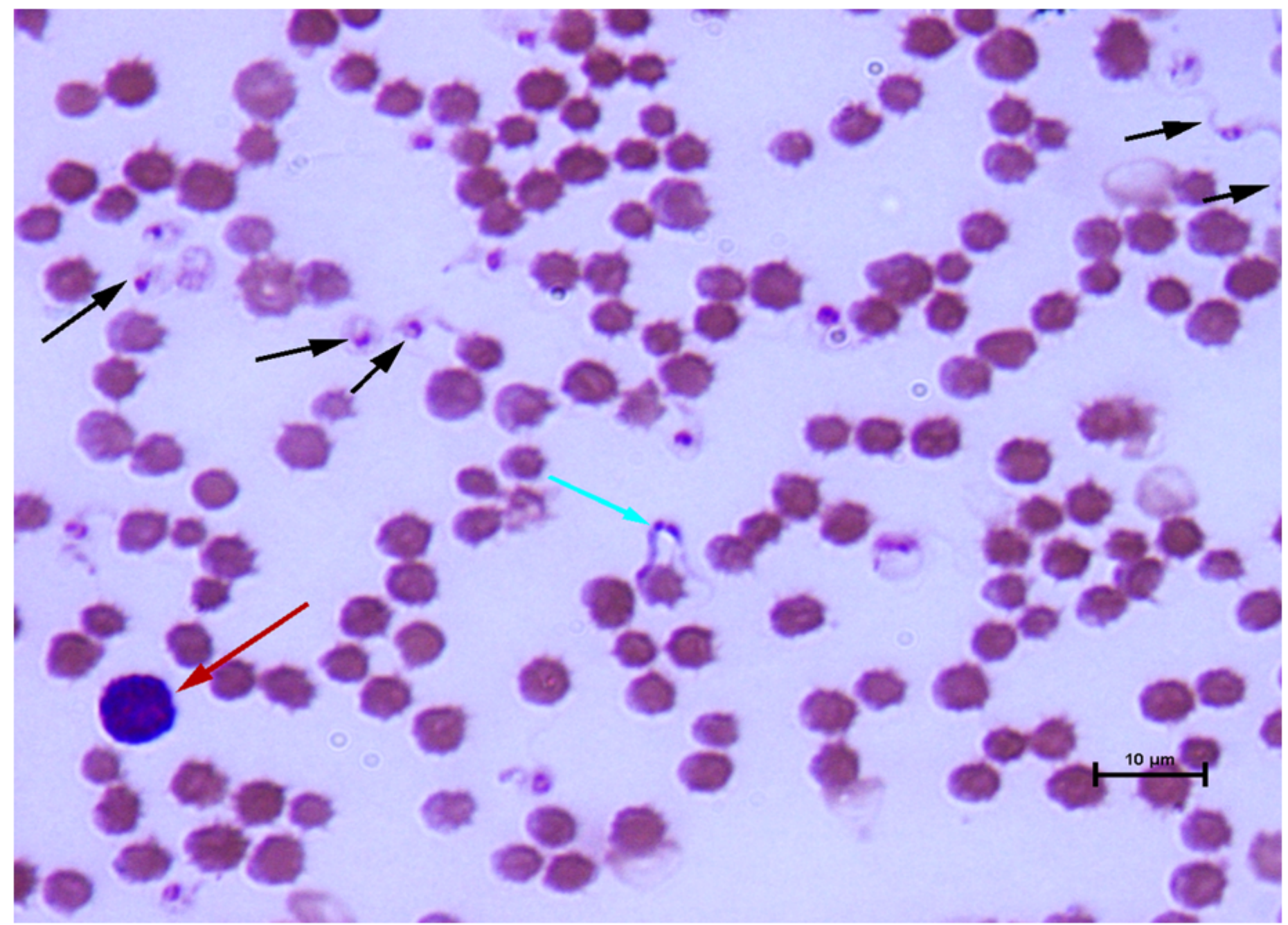

Figure 1

Black and blue arrows showing numerous Trypanosoma evansi in Giemsa stained Kedah-Kelantan X Brahman cattle thin blood smear. Red arrow shows a lymphocyte and background red blood cells were crenated. Magnification x1000 


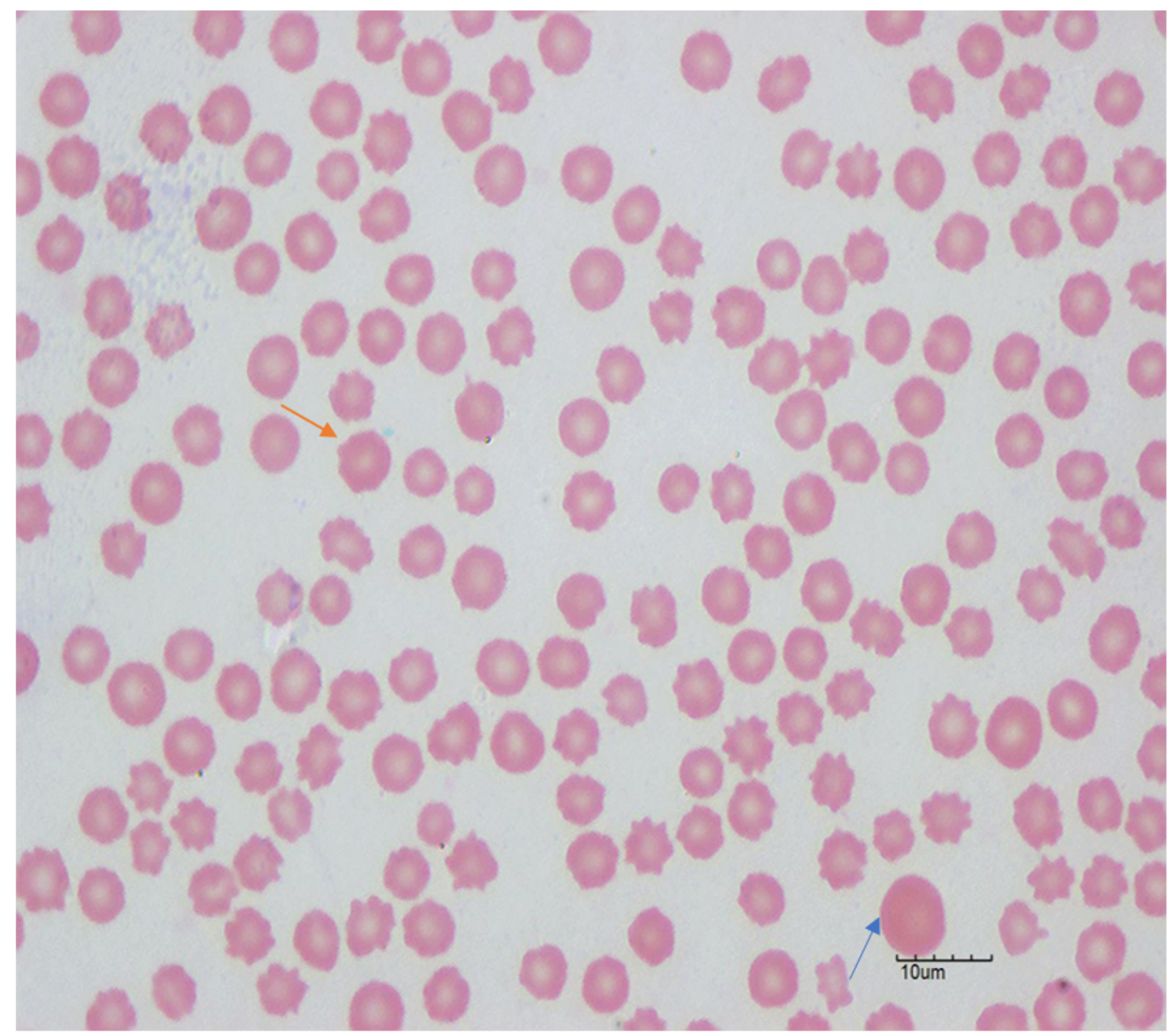

Figure 2

A wright-stained thin blood smear from Anaplasma platys + Theileria sinensis (confirmed by PCR and sequencing) double species coinfected Kedah-Kelantan X Brahman cattle group showing an echinocyte (orange arrow) and a macrocyte (blue arrow). Poikilocytosis is evident. Presence of macrocytes in signifies bone marrow response. Magnification x1000 


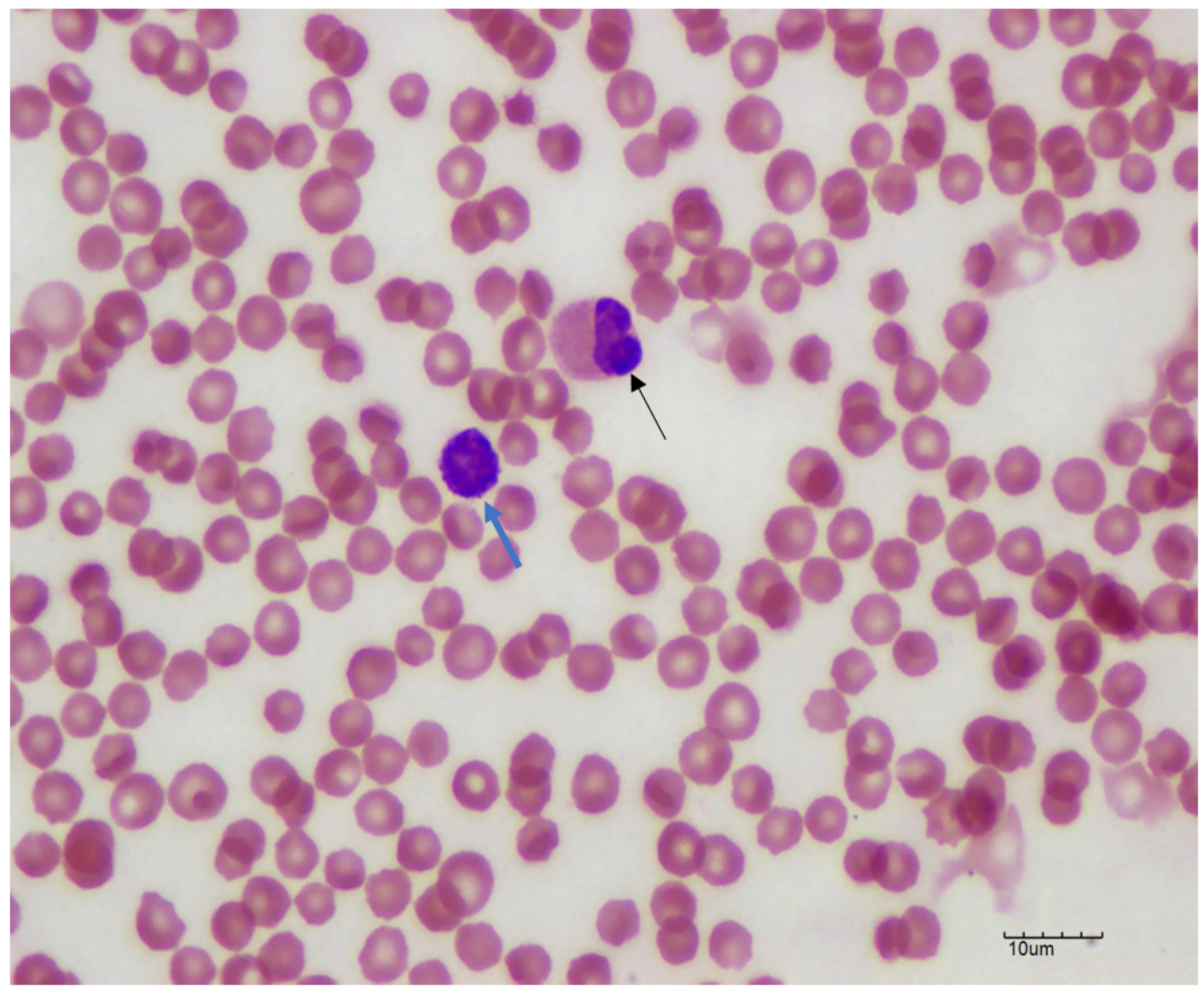

Figure 3

Wright stained thin blood smear from Anaplasma marginale $\mathrm{x}$ T. orientalis (confirmed by PCR) double species co-infected Kedah-Kelantan $\mathrm{X}$ Brahman cattle group showing metamyelocyte (Black arrow), lymphocyte (blue arrow) with background erythrocytes of different sizes, and rouleaux formation. Magnification x1000. 


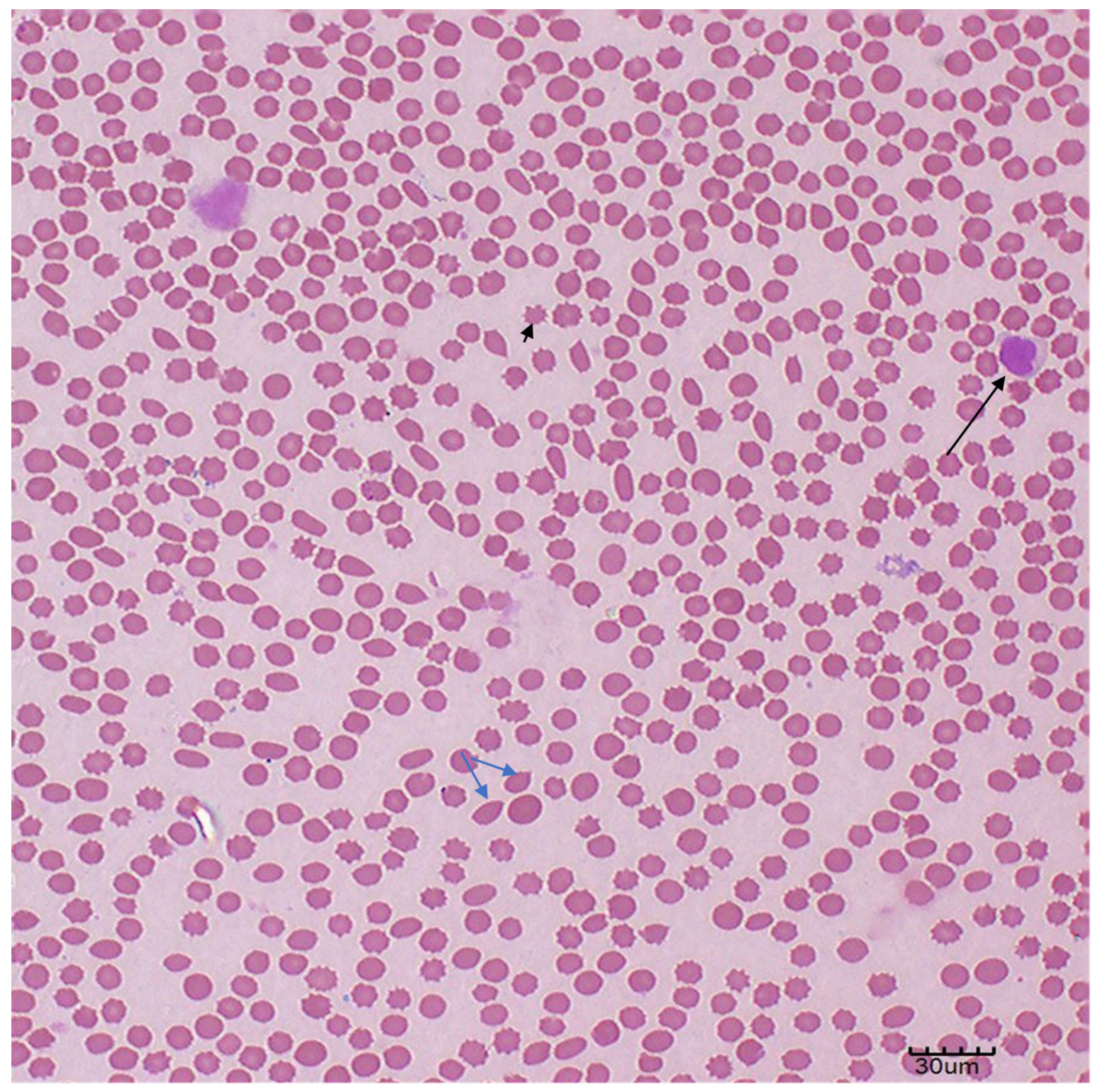

\section{Figure 4}

Wright stained thin blood smears from Theileria orientalis + T. sinensis (confirmed by PCR and sequencing) double species co-infected Kedah-Kelantan X Brahman cattle group showing numerous background erythrocytes of different shapes (double blue arrow) elliptocytes, (Blue double arrows) echinocytes (black arrowhead) and red cells of varying sizes. Black arrow shows a monocyte. Magnification x600 


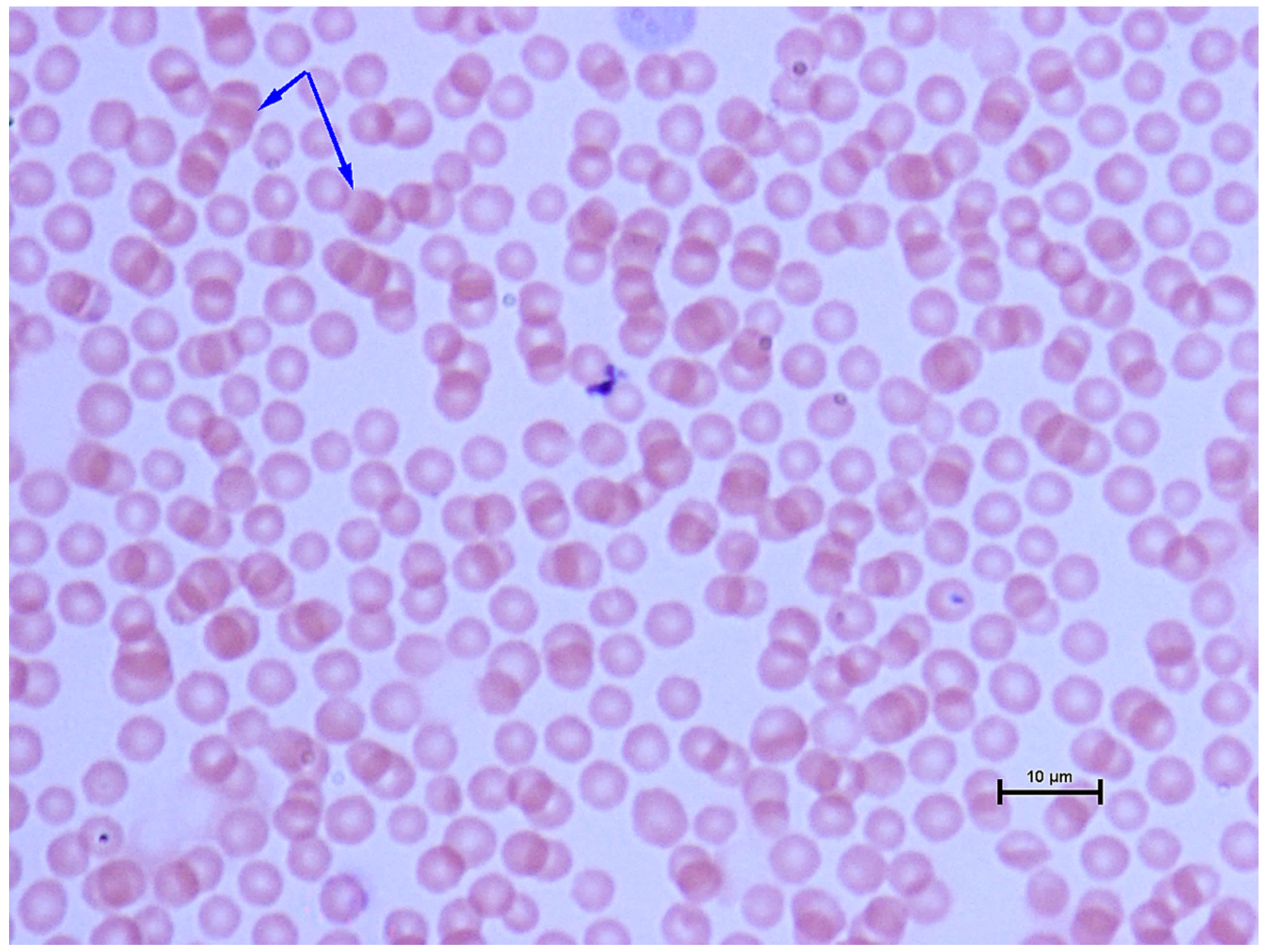

\section{Figure 5}

Wright stained thin blood smear of C. M. haemobos + T. sinensis (confirmed by PCR and sequencing) double species co-infected KedahKelantan X Brahman cattle group from Muadzam Pahang showing marked rouleaux formation with normal sized red blood cells.

Rouleaux formation occurs in cases of hyperglobulinemia in mammals. Magnification x1000 


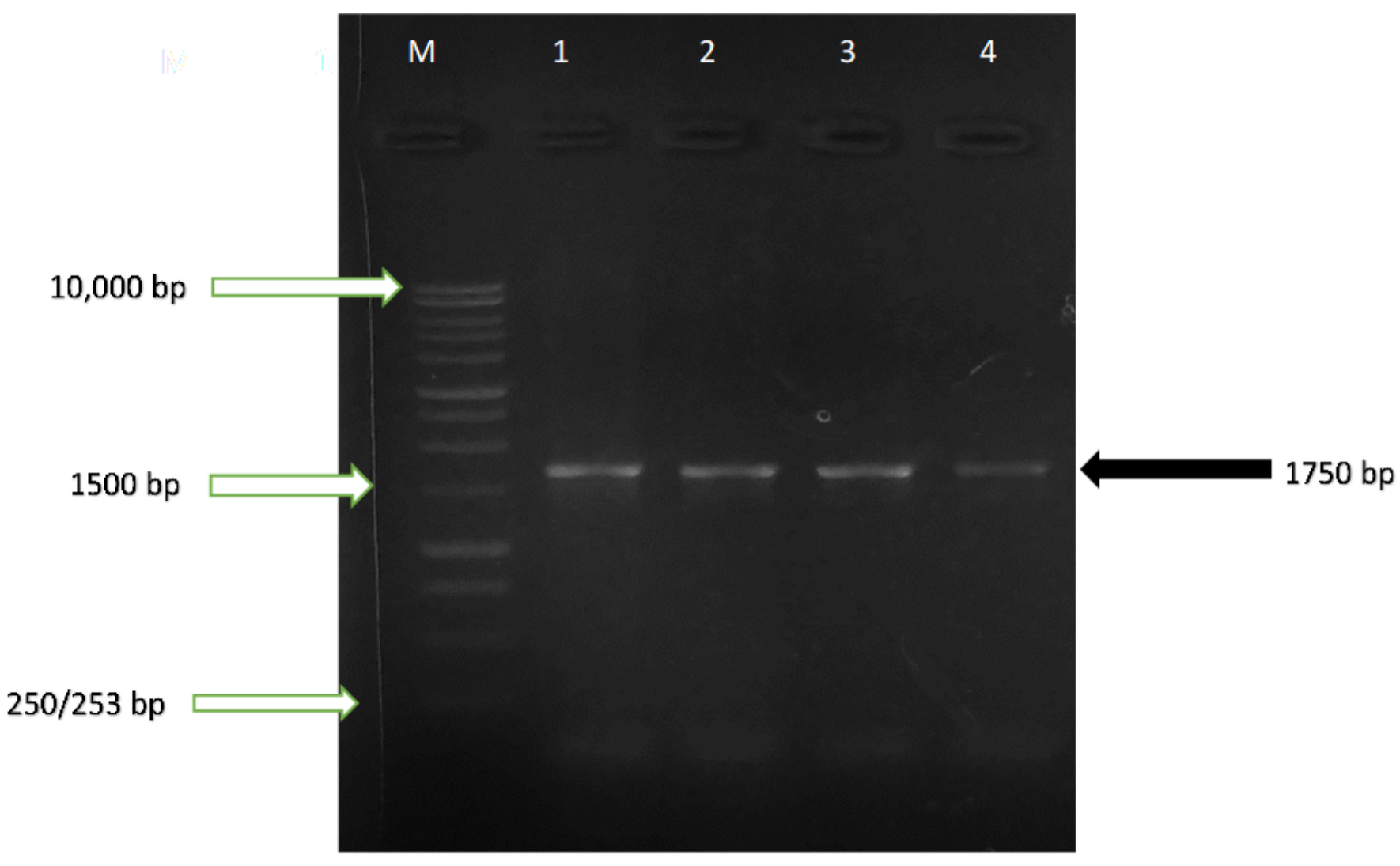

\section{Figure 6}

$1.2 \%$ agar rose gel electrophoresis image showing a $1750 \mathrm{bp}$ band for $18 \mathrm{~S}$ ribosomal RNA gene of Theileria species amplified from blood samples of Kedah-Kelantan X Brahman cattle at Muadzam Pahang Malaysia. Lane M: 1kb molecular size marker (Promega, USA).; Lanes 1-4: Positive cattle DNA samples. Nucleic acid stain: RedSafe®. 


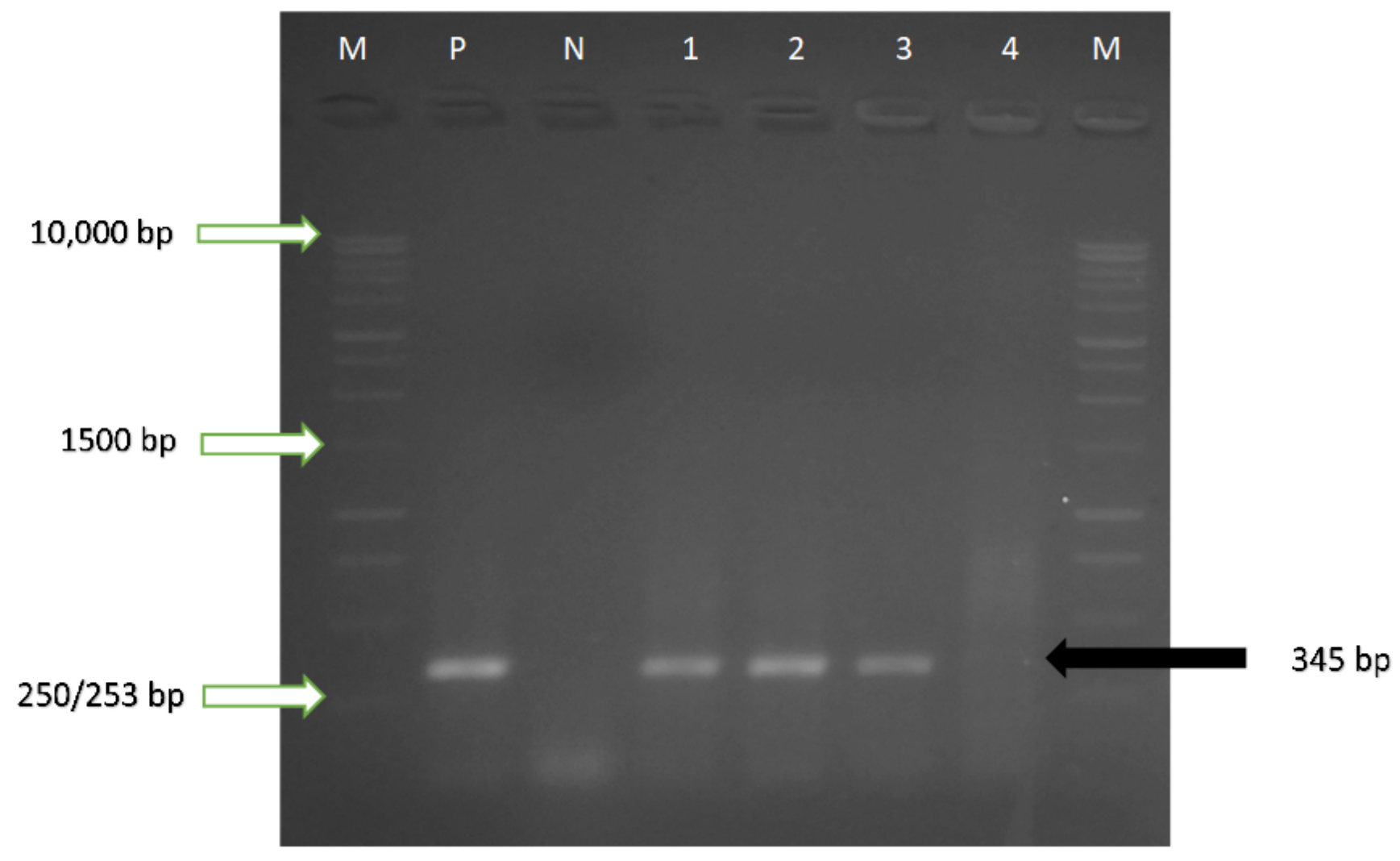

\section{Figure 7}

$1.2 \%$ agar rose gel electrophoresis image showing a $345 \mathrm{bp}$ band for $16 \mathrm{~S}$ ribosomal RNA gene of Anaplasma species amplified from blood samples of Kedah-Kelantan X Brahman cattle at Muadzam Pahang Malaysia. Lanes M: 1 kb molecular size markers (Promega, USA). Lane P: Positive test control (field positive sample); Lane N: Negative PCR control (no DNA template); Lanes 1-3: Positive KedahKelantan X Brahman cattle DNA samples. Lane 4: Negative cattle DNA samples. Nucleic acid stain: RedSafe®. 


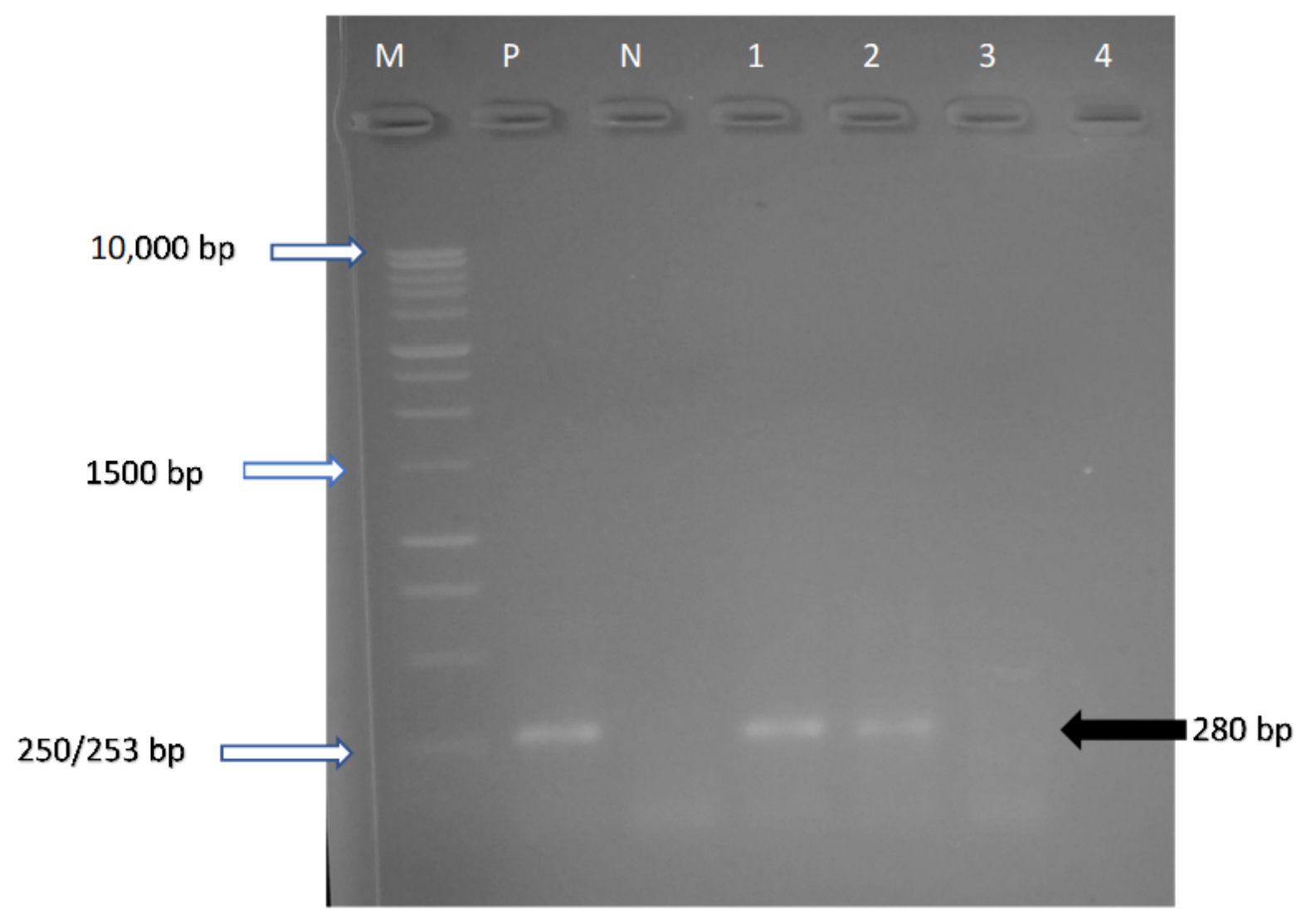

\section{Figure 8}

$1.2 \%$ agar rose gel electrophoresis image showing a $280 \mathrm{bp}$ band for $16 \mathrm{~S}$ ribosomal RNA gene of Mycoplasma species amplified from blood samples of Kedah-Kelantan X Brahman cattle at Muadzam Pahang Malaysia. Lane M: $1 \mathrm{~kb}$ molecular size markers (Promega, USA). Lane P: Positive control (field positive sample); Lane N: Negative PCR control (no DNA template); Lanes 1-2: positive cattle samples; Lane 3-4: Negative cattle samples. Nucleic acid stain: RedSafe®.

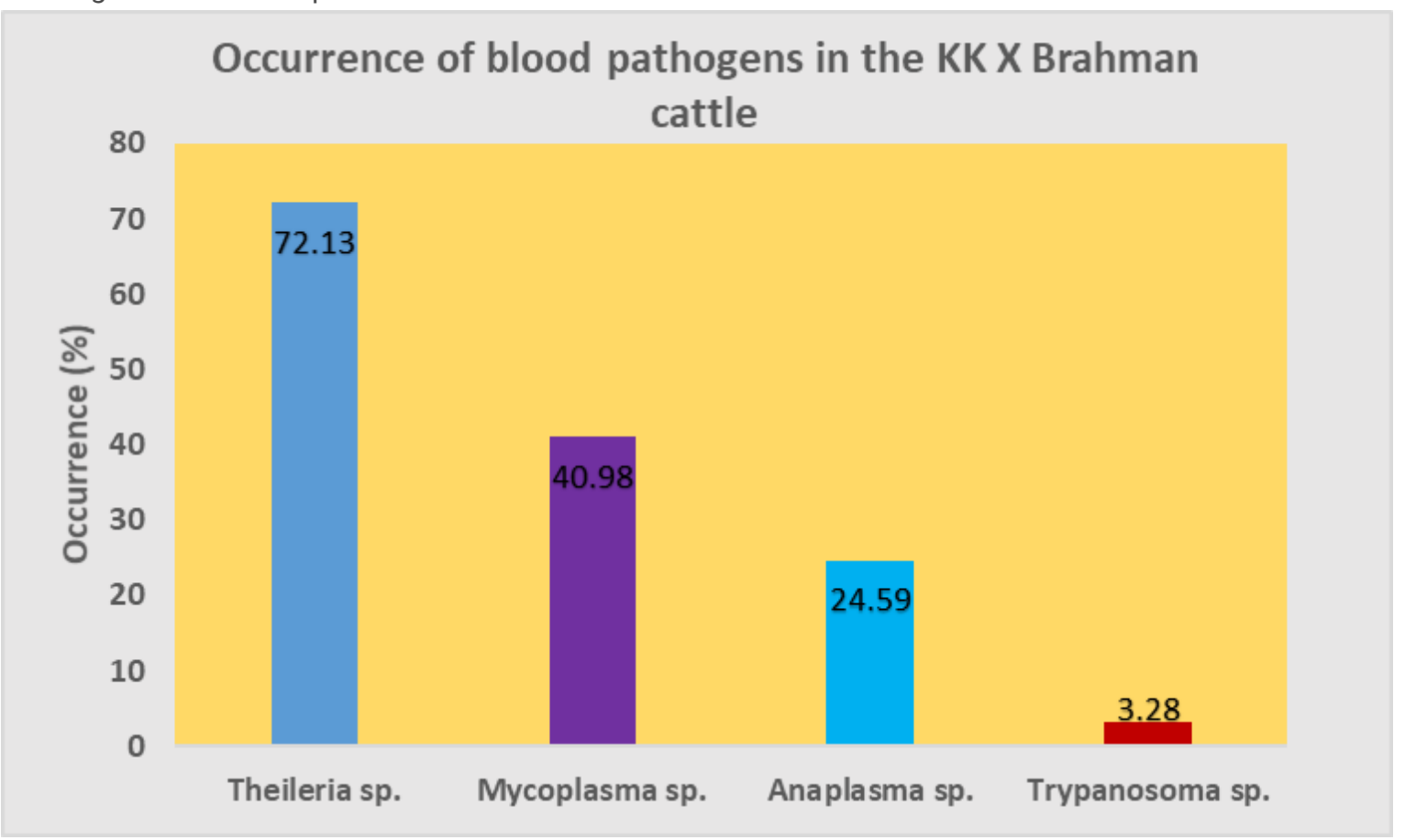




\section{Figure 9}

Percentage occurrence of Theileria, Mycoplasma, Anaplasma and Trypanosoma species detected and confirmed by PCR amplificationand sequencing, in the Kedah-Kelantan x Brahman cattle sampled in Muadzam, Pahang Malaysia.

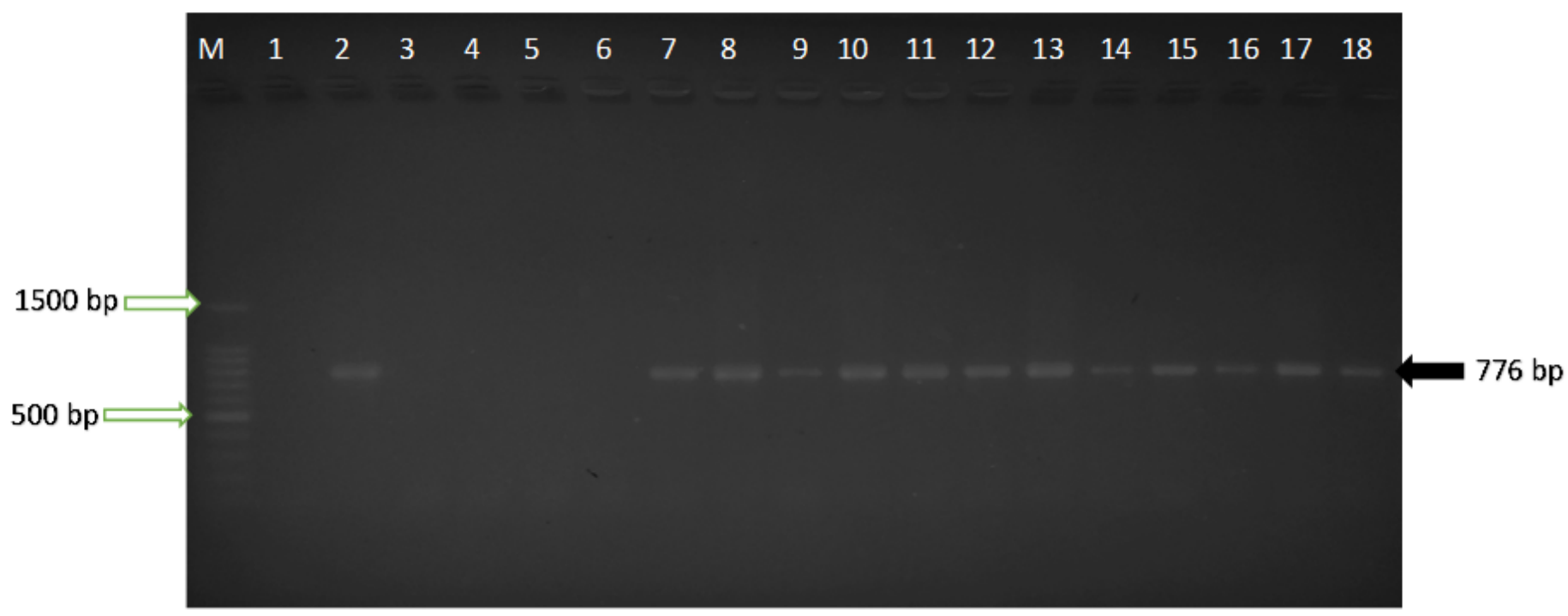

\section{Figure 10}

1.5\% agar rose gel electrophoresis image showing a $776 \mathrm{bp}$ band for major piroplasm surface protein (MPSP) gene of Theileria orientalis amplified from blood samples of Kedah-Kelantan X Brahman cattle at Muadzam Pahang Malaysia. Lane M: 100 bp molecular size markers (Promega, USA). Lane 1: Negative PCR control (no DNA template); Lane 2: Positive test control (field positive sample); Lanes 3-6: Negative cattle DNA samples; Lanes 7-18: Positive cattle DNA samples. Nucleic acid stain: RedSafeß

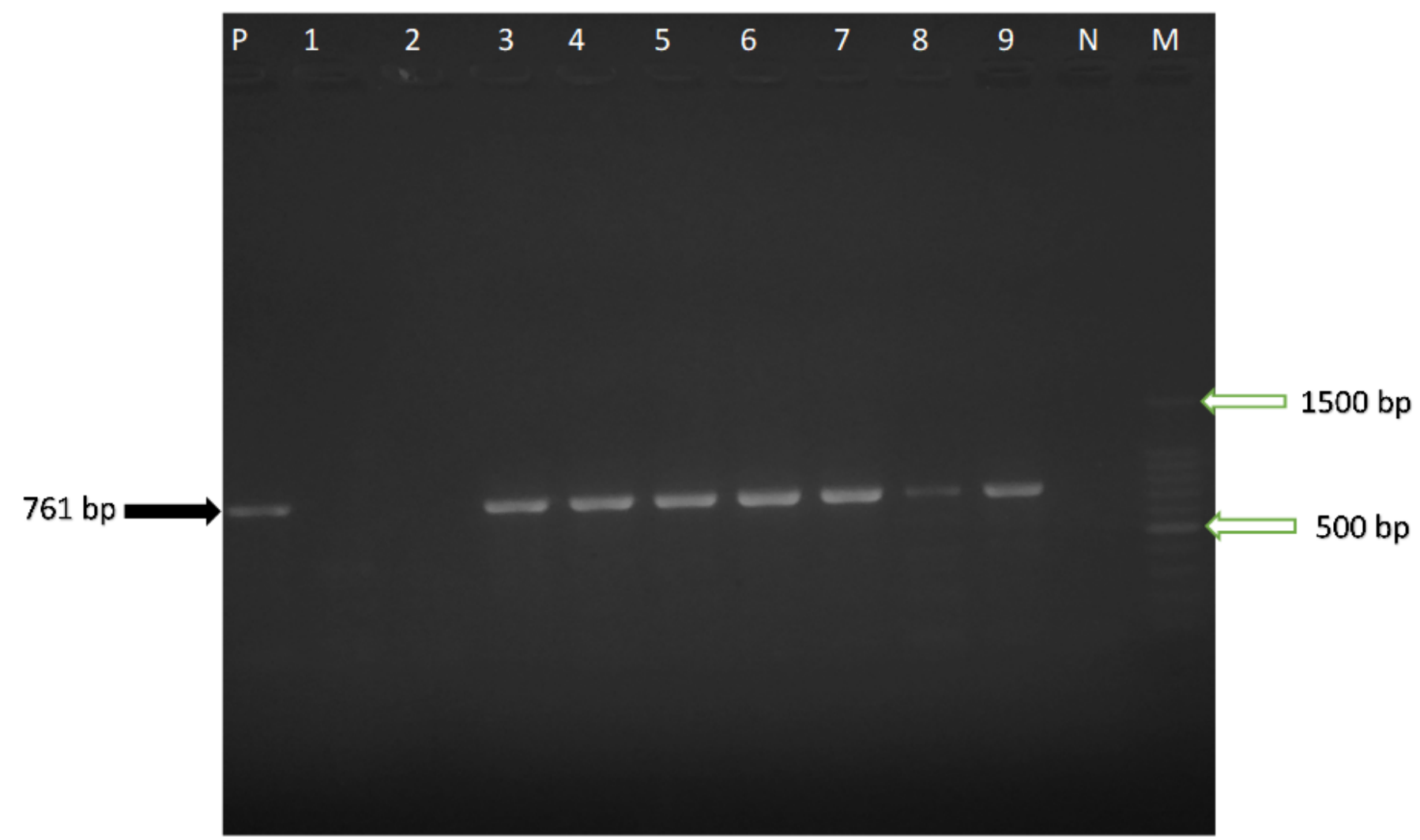




\section{Figure 11}

1.5\% agar rose gel electrophoresis image showing a $761 \mathrm{bp}$ band for major surface protein 4 (MSP4) gene of Anaplasma marginale amplified from blood samples of Kedah-Kelantan X Brahman cattle at Muadzam Pahang Malaysia. Lanes M: 100 bp molecular size markers (Promega, USA). Lane P: Positive test control (field positive sample) Lane N: Negative PCR control (no DNA template); Lanes 1-2: Negative cattle DNA samples; Lanes 3 - 9: Positive cattle DNA samples. Nucleic acid stain: RedSafe ${ }^{\text {. }}$

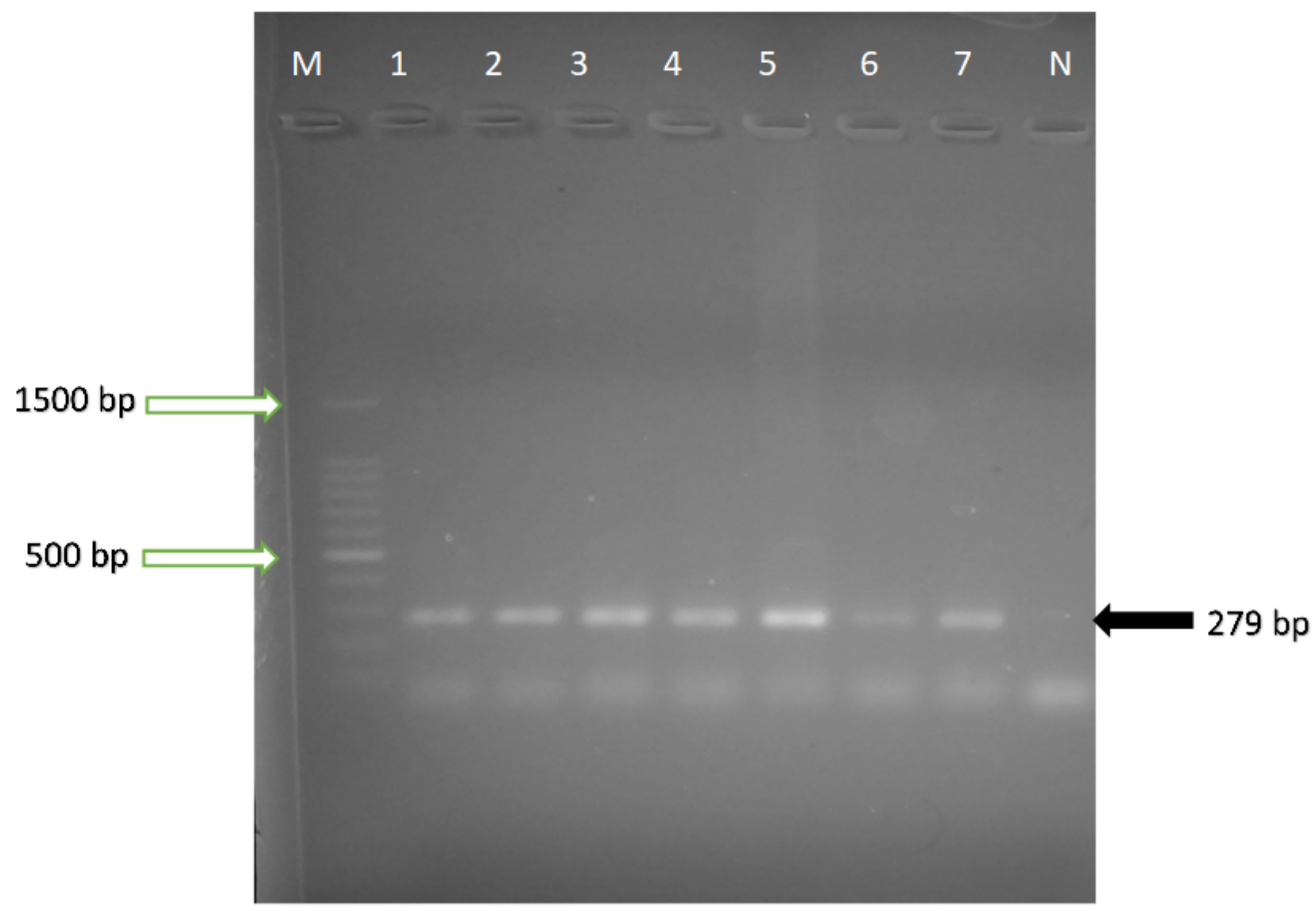

Figure 12

$1.5 \%$ agar rose gel electrophoresis image showing a 279 bp band for $16 \mathrm{~S}$ ribosomal RNA gene of Candidatus M. haemobos amplified from blood samples of Kedah-Kelantan X Brahman cattle at Muadzam Pahang Malaysia. Lanes M: 100 bp molecular size markers (Promega, USA). Lanes 1-7: Positive cattle DNA samples; Lane N: Negative control (no DNA template); Nucleic acid stain: RedSafe ${ }^{\circledR}$. 


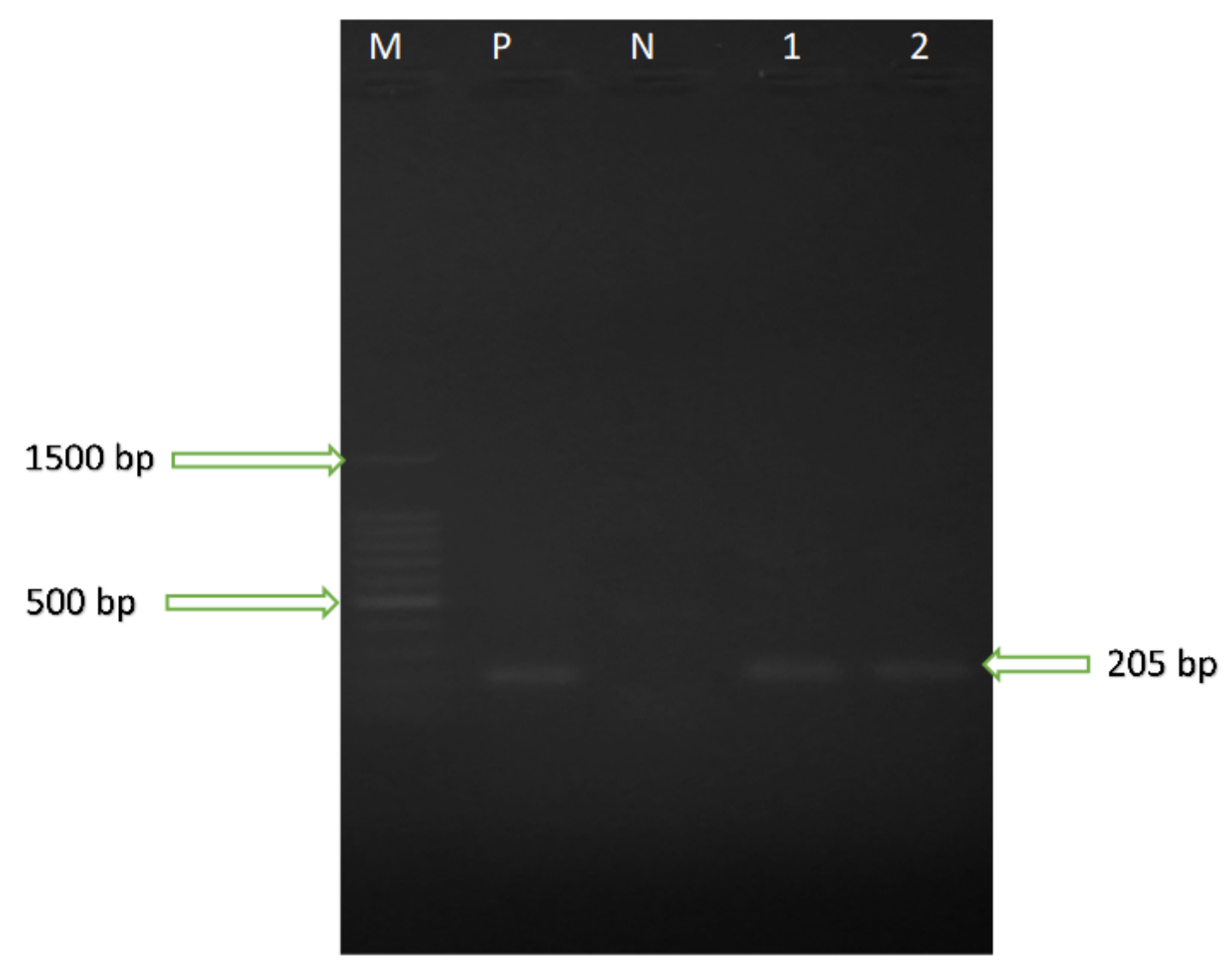

\section{Figure 13}

1.5\% agar rose gel electrophoresis image showing a 205 bp band for RoTaT 1.2 VSG gene of Trypanosoma evansi amplified from blood samples of Kedah-Kelantan X Brahman cattle at Muadzam Pahang Malaysia. Lanes M: 100 bp molecular size markers (Promega, USA). Lane P: Positive test control (field positive sample) Lane N: Negative PCR control (no DNA template); Lanes 1-2: Positive cattle samples. Nucleic acid stain: RedSafe®. 


\section{Single, double and triple species co-infection in the Kedah- Kelantan X Brahman Cattle}

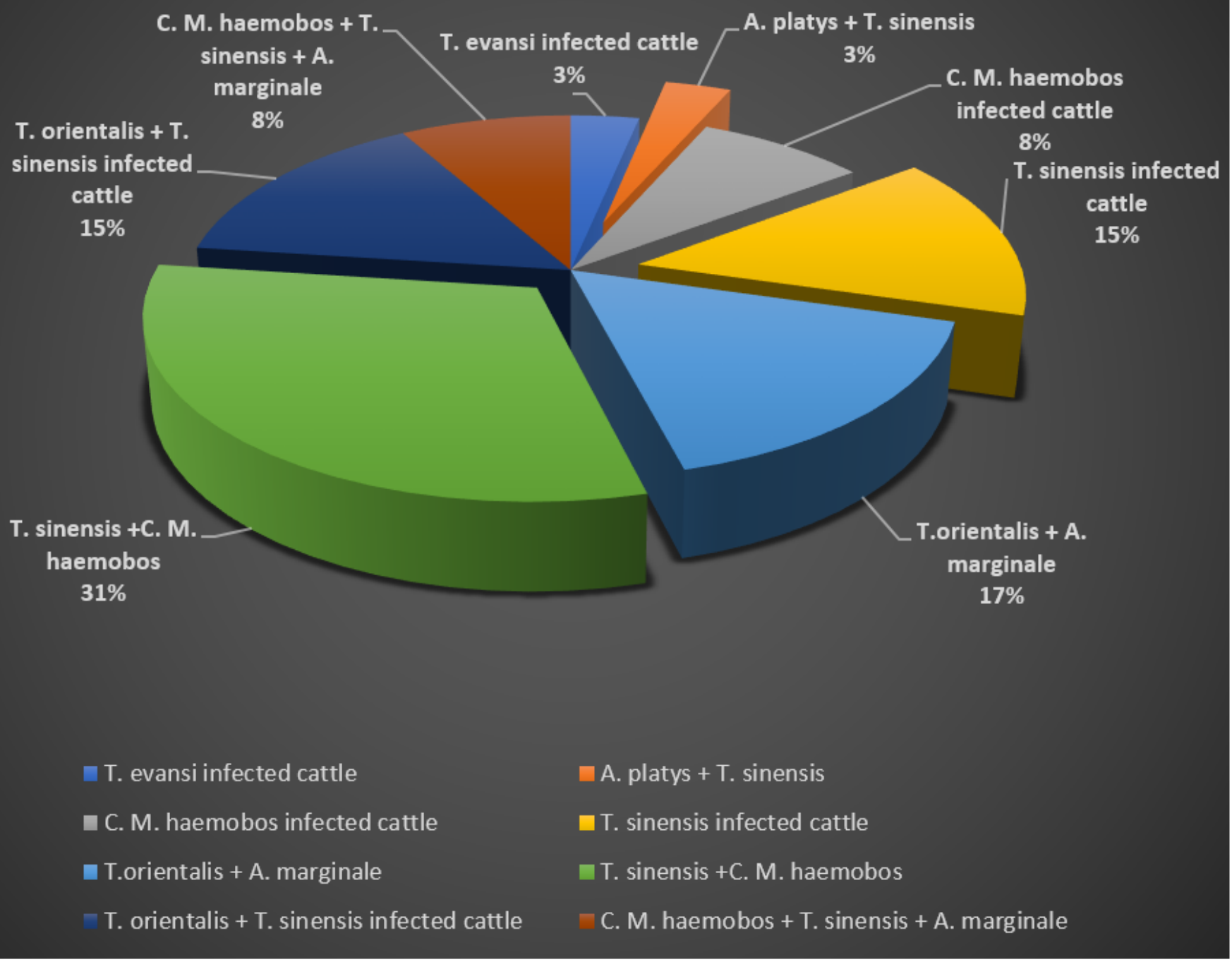

\section{Figure 14}

Percentage occurrence of single, double and triple species co-infection in the Kedah-Kelanatn $x$ Brahman cattle. The animals were categorized according to single, double and triple species co-infections, based on PCR amplification of species-specific genes. T. sinensis + C. M. haemobos double species co-infection had the highest occurrence. 


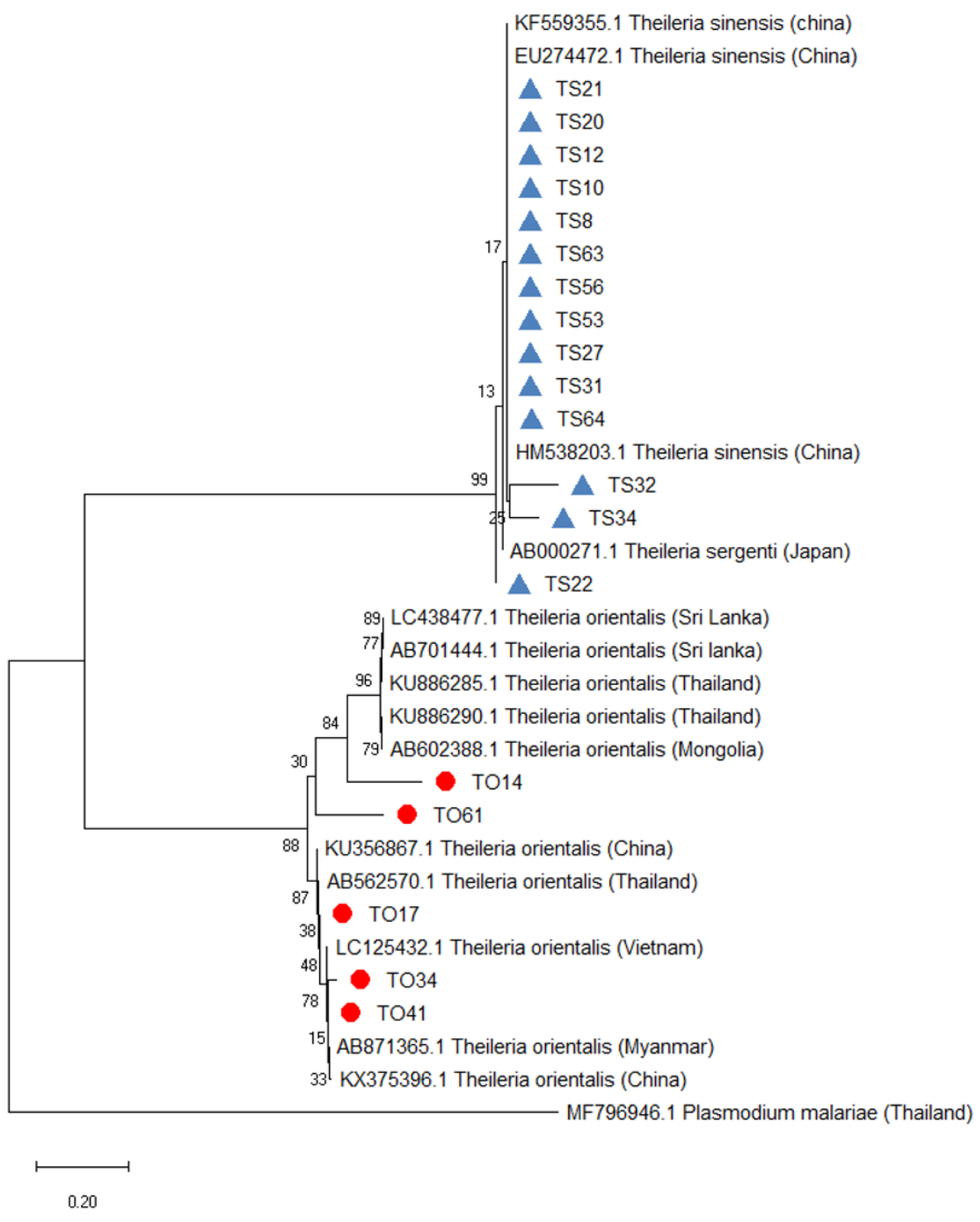

Figure 15

Phylogenetic tree showing taxonomic relationships of Theileria orientalis and Theileria sinensis detected from Kedah Kelantan x Brahman cattle in Muadzam Pahang Malaysia. The relationships were inferred based on MPSP gene for T. orientalis (776 bp) from 10 reference sequences of Theileria orientalis and 18SrRNA gene of Theileria species from 3 reference sequences of Theileria sinensis. Theileria sergenti reference isolate from Japan were used for comparison. Plasmodium malariae was used as an outgroup. Phylogenetic reconstruction was performed in MEGA X using maximum likelihood analysis based on the general time-reversible model. Support for each node was indicated by 1000 bootstrap resamplings. The scale bar represents the number of substitutions per site. For each sequence, the full species names are followed up by the country where they were isolated. The accession numbers are given at beginning of each sequence label. Five (5) T. orientalis and fourteen (14) T. sinensis isolates from Muadzam Pahang Malaysia are marked with a solid red circle and blue triangles respectively. 


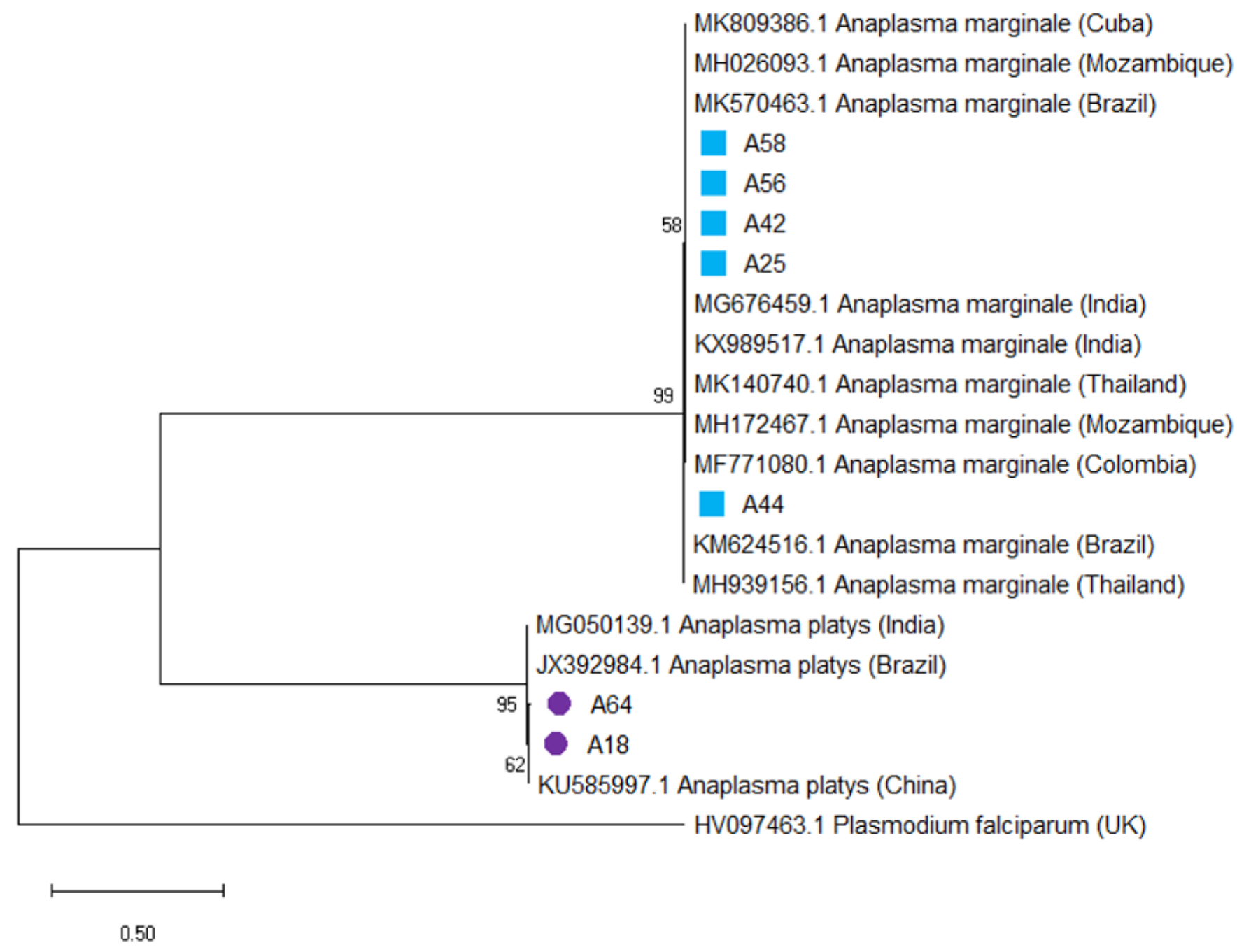

Figure 16

Maximum Likelihood analysis of the 16SrRNA of Anaplasma species and msp4 gene of A. marginale sequences showing the phylogenetic relationship of the Anaplasma spp. Plasmodium falciparium was used as an outgroup. The scale bar represents the number of substitutions per site. For each sequence, the full species names are followed up by the country where they were isolated. The accession numbers are given at beginning of each sequence label. Two (2) A. platys and five (5) A. marginale isolates from Pahang Malaysia are marked with a solid purple circle and blue solid square respectively. 


\section{Erythrocyte osmotic fragility curve}

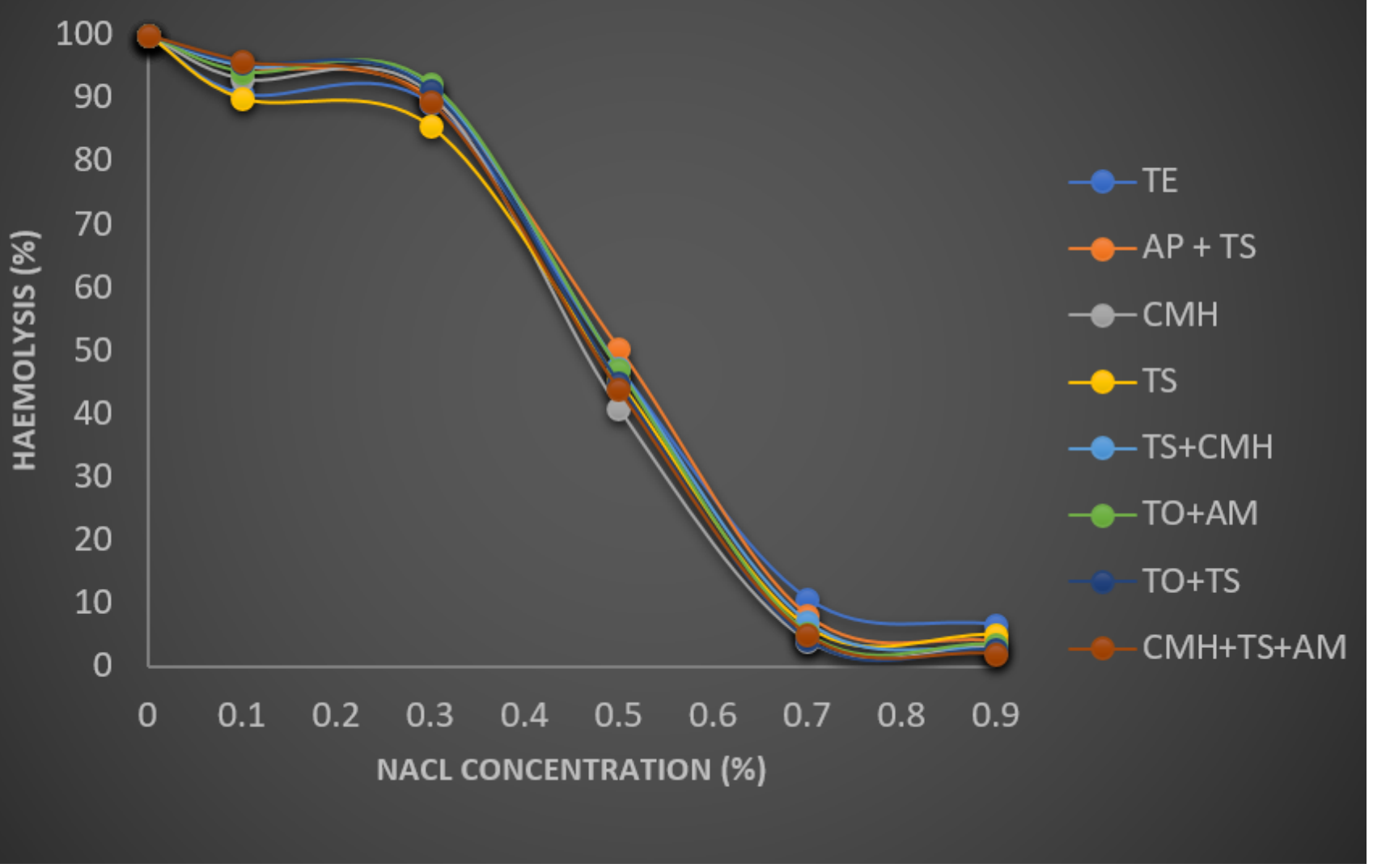

\section{Figure 17}

The erythrocyte osmotic fragility curves of the different blood pathogen infected Kedah-Kelantan X Brahman cattle groups from Muadzam Pahang Malaysia. Blood pathogen infection was confirmed by PCR amplification and sequencing. The erythrocyte osmotic fragility values were obtained by subjecting blood samples to different sodium chloride $(\mathrm{NaCl})$ concentrations $(0-0.9 \%)$. All curves showed a rightward trend which signifies high fragility of red blood cells. TE: Trypanosoma evansi infected cattle; AP + TS: Anaplasma platys + Theileria sinensis ;CMH: Candidatus Mycoplasma haemobos infected cattle; TS: Theileria sinensis infected cattle; TO + AM: Theileria orientalis + A. marginale infected cattle, TS+CMH: Theileria sinensis +Candidatus Mycoplasma haemobos infected cattle, TO+TS: Theileria orientalis + Theileria sinensis infected cattle; CMH + TS + AM: Candidatus Mycoplasma haemobos + Theileria sinensis + Anaplasma marginale infected cattle. 


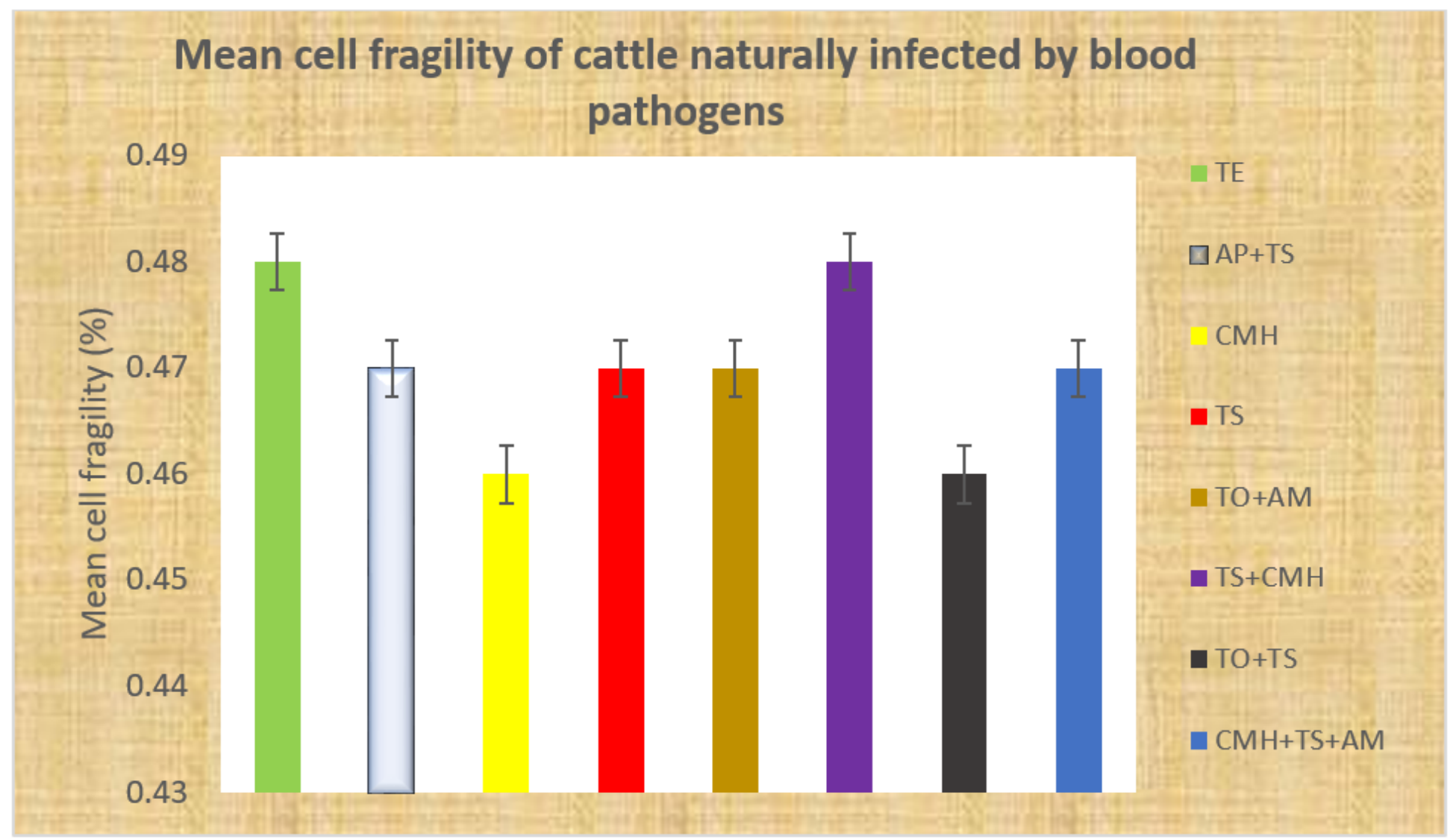

\section{Figure 18}

The mean cell fragility (MCF) values of different naturally infected Kedah-Kelantan x Brahman cattle groups from Muadzam Pahang Malaysia. The MCF values were extrapolated from the erythrocyte osmotic fragility curve in Figure 19. TE: Trypanosoma evansi infected cattle; AP + TS: Anaplasma platys + Theileria sinensis ;CMH: Candidatus Mycoplasma haemobos infected cattle; TS: Theileria sinensis infected cattle; TO + AM: Theileria orientalis + A. marginale infected cattle, TS+CMH: Theileria sinensis +Candidatus Mycoplasma haemobos infected cattle, TO+TS: Theileria orientalis + Theileria sinensis infected cattle; CMH + TS + AM: Candidatus Mycoplasma haemobos + Theileria sinensis + Anaplasma marginale infected cattle. 